\title{
Zinc finger protein 637 protects cells against oxidative stress-induced premature senescence by mTERT-mediated telomerase activity and telomere maintenance
}

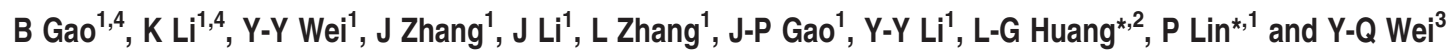

Oxidative stress is believed to be an important inducer of cellular senescence and aging. Zinc finger protein 637 (Zfp637), which belongs to the Krüppel-like protein family, has been hypothesized to play a role in oxidative stress. Nevertheless, the precise function of Zfp637 has seldom been reported, and it remains unclear whether Zfp637 is involved in oxidative stress-induced premature senescence. In this study, we show that the endogenous expression levels of Zfp637 and mouse telomerase reverse transcriptase (mTERT) are downregulated during oxidative stress-induced premature senescence and in senescent tissues from naturally aged mice. The overexpression of Zfp637 markedly increases mTERT expression and telomerase activity, maintains telomere length, and inhibits both $\mathrm{H}_{2} \mathrm{O}_{2}$ and D-galactose-induced senescence accompanied by a reduction in the production of reactive oxygen species (ROS). In contrast, the knockdown of Zfp637 significantly aggravates cellular senescence by downregulating mTERT and telomerase activity, accelerating telomere shortening, and increasing ROS accumulation. In addition, the protective effect of Zfp637 against premature senescence is abrogated in the absence of mTERT. We further confirm that Zfp637 binds to and transactivates the mTERT promoter $(-535 /-502)$ specifically. As a result, the mTERT-mediated telomerase activity and telomere maintenance are responsible for the protective effect of Zfp637 against oxidative stressinduced senescence. We therefore propose that Zfp637 prevents oxidative stress-induced premature senescence in an mTERTdependent manner, and these results provide a new foundation for the investigation of cellular senescence and aging.

Cell Death and Disease (2014) 5, e1334; doi:10.1038/cddis.2014.298; published online 17 July 2014

Cellular senescence can be defined as an irreversible cell cycle arrest accompanied by exhaustion of the replicative potential. ${ }^{1}$ Three major mechanisms of cellular senescence have been proposed. Replicative senescence likely results from alteration of the telomere lengths or structures, such as telomeric fusion or a loss of telomere-bound factors. ${ }^{2}$ Oncogene-induced senescence is closely associated with activated oncogenes, such as Ras and Raf, that trigger a senescence-like growth arrest. ${ }^{3,4}$ Cells also enter a senescent state subjected to various types of sublethal stressors, including oxidative stress, and this state is referred to as stress-induced premature senescence. ${ }^{5,6}$

According to the free-radical theory, oxidative stress mediated by reactive oxygen species (ROS) participates in senescence and age-related diseases. ${ }^{7}$ In general, ROS function as messenger molecules activating specific redox-dependent targets and it is the activation of these targets that induces senescence, but not the level of ROS per se. ${ }^{8}$ Oxidative stress-induced premature senescence is established after several days of exposure to subcytotoxic concentrations of numerous types of oxidants. For example, exogenous $\mathrm{H}_{2} \mathrm{O}_{2}$ has been used extensively as an inducer of oxidative stress in in vitro models. ${ }^{9,10}$ In addition, a low dose of $\mathrm{D}$-galactose (D-gal) induces cellular senescence and resembles natural aging in animals. ${ }^{11-13}$ The oversupply of $\mathrm{D}-\mathrm{gal}$, a physiological nutrient, results in abnormal metabolism. D-gal is converted into galactitol, which is not metabolized normally but rather accumulated in cells to result in osmotic stress and oxidative stress by promoting endogenous ROS generation. ${ }^{14}$

Telomeres, which consist of tandem repeats of the TTAGGG sequence, serve as essential protective caps of the linear chromosomal ends in mammalian cells. ${ }^{15}$ Telomerase, a ribonucleoprotein complex containing a template RNA subunit, a telomerase-associated protein, and a telomerase reverse

\footnotetext{
${ }^{1}$ Division of Experimental Oncology, State Key Laboratory of Biotherapy, West China Hospital, Sichuan University, Chengdu, China; ${ }^{2}$ Department of Pediatric Surgery, West China Hospital, Sichuan University, Chengdu, China and ${ }^{3}$ Division of Cancer Biotherapy, State Key Laboratory of Biotherapy, West China Hospital, Sichuan University, Chengdu, China

${ }^{*}$ Corresponding authors: L-G Huang, Department of Pediatric Surgery, West China Hospital, Sichuan University, Chengdu, China. Tel: + 862885422459 ; Fax: + 8628 85582944; E-mail: Lugang992001@aliyun.com

or P Lin, Division of Experimental Oncology, State Key Laboratory of Biotherapy, West China Hospital, Sichuan University, Chengdu, China. Tel: +862885164016 ; Fax: + 8628 85582944; E-mail: linping8@yahoo.com

${ }^{4}$ These authors contributed equally to this work.

Abbreviations: Zfp637, zinc finger protein 637; mTERT, mouse telomerase reverse transcriptase; ROS, reactive oxygen species; D-gal, D-galactose; DAPI, 4',6-diamidino-2-phenylindole; SAHF, senescence-associated heterochromatin foci; SA- $\beta$-gal, senescence-associated $\beta$-galactosidase; shNC, shRNA-negative control; shZfp637, shRNA-zinc finger protein 637; siRNA, small interfering RNA; qRT-PCR, quantitative real-time PCR; EMSA, electrophoretic mobility shift assay; GAPDH, glyceraldehyde-phosphate dehydrogenase; DCFH-DA, 2',7'-dichlorodihydrofluorescein diacetate; PBS, phosphate-buffered saline; LDH, lactic dehydrogenase Received 03.1.14; revised 04.6.14; accepted 05.6.14; Edited by H-U Simon
} 
transcriptase (TERT), extends telomeres length by adding telomeric repeats to the chromosome ends. ${ }^{16}$ In most cells, TERT is the critical rate-limiting component responsible for the catalytic activity of telomerase. ${ }^{17}$

Numerous evidences suggest that telomeres and telomerase have important roles in senescence in vitro and in vivo. ${ }^{18}$ It has been shown that the production of high levels of ROS results in a disturbance of the redox balance and shifts cells into a state of oxidative stress, which subsequently leads to premature senescence with the shortening of telomeres. ${ }^{9}$ The transfection of TERT into normal somatic cells can reconstitute the telomerase activity, maintain telomeres, and extend their replicative life span. ${ }^{19}$ Mouse TERT (mTERT) overexpression in primary murine embryonic fibroblasts favors their proliferation, escapes from premature senescence, and oncogene-induced colony formation. ${ }^{20}$ The constitutive expression of TERT in cancer-resistant mice produces a systemic delay in aging accompanied by an extension of the median life span. ${ }^{21}$ Moreover, studies have demonstrated that mTERT can be regulated by many transcription factors, including Sp1, c-Myc, and nuclear factor- $\kappa \mathrm{B}^{22,23}$ These results suggest that the downregulation of TERT by several transcription factors may reduce the telomerase activity such that cells enter senescence.

Zinc finger proteins have been implicated as transcription factors in a variety of pathophysiological processes, including embryo development, hormone secretion, cell differentiation, senescence, and apoptosis. Zfp637, a zinc finger protein of Mus musculus (GenBank ID: 232337) that belongs to the Krüppel-like protein family, comprises six consecutively typical and one atypical $\mathrm{C} 2 \mathrm{H} 2$ zinc finger motifs. We have reported that Zfp637 is located in nucleus and behaves as a repression regulator in myogenic cellular differentiation by promoting mTERT expression. ${ }^{24}$ Based on its structural characterization and location, we predict that Zfp637 likely acts as a DNA-binding protein to regulate gene transcription. An analysis of Zfp637 in the NCBI Gene Expression Omnibus (http://www.ncbi.nlm.nih.gov/geo/) indicates that Zfp637 may have a potential role in oxidative stress, ${ }^{25-27}$ and our previous study proved that Zfp637 expression was significantly altered in NIH3T3 cells treated with $200 \mu \mathrm{M} \mathrm{H}_{2} \mathrm{O}_{2}$ in a time-dependent manner. ${ }^{28}$

In this study, we examined the expression of Zfp637 and mTERT in senescent NIH3T3 and C2C12 cells induced by $\mathrm{H}_{2} \mathrm{O}_{2}$ and D-gal, respectively. We then examined the effect of Zfp637 overexpression or knockdown on oxidative stressinduced premature senescence. To elucidate the mechanism through which Zfp637 regulates cell senescence, we further explored the potential transcriptional regulation between Zfp637 and mTERT during senescence induction. Furthermore, the expression of Zfp637 and mTERT in several organ tissues from aged BALB/C mice was detected to confirm the correlation between their expression levels during aging in vivo.

\section{Results}

Zfp637 expression is repressed in oxidative stress-induced premature senescence. To investigate oxidative stressinduced senescence, we first established a $\mathrm{H}_{2} \mathrm{O}_{2}$-induced senescence model for the mouse fibroblast cell line NIH3T3. To determine an effective non-cytotoxic concentration, cells were treated with various concentrations $(0-250 \mu \mathrm{M})$ of $\mathrm{H}_{2} \mathrm{O}_{2}$ for $96 \mathrm{~h}$, at which time the morphological phenotype of cellular senescence was observed. We then conducted Annexin V-FITC-binding assay and subsequently performed a flow cytometric analysis. As shown in Supplementary Figure 1a, a large number of cells underwent apoptosis upon exposure to higher concentrations (200 and $250 \mu \mathrm{M})$ of $\mathrm{H}_{2} \mathrm{O}_{2}$, whereas the percentage of apoptotic cells was not higher than $7.5 \%$ in the presence of lower concentrations $(50,100$ and $150 \mu \mathrm{M}$ ) of $\mathrm{H}_{2} \mathrm{O}_{2}$. Necrotic cell death was evaluated by quantifying the release of the stable cytosolic enzyme lactic dehydrogenase (LDH). LDH release assay showed that 50 and $100 \mu \mathrm{M} \mathrm{H}_{2} \mathrm{O}_{2}$ treatment did not induce statistically significant increases in the intracellular $\mathrm{LDH}$ released into the culture medium. However, 200 and $250 \mu \mathrm{M} \mathrm{H}_{2} \mathrm{O}_{2}$ resulted in cell damage, as the amount of released $\mathrm{LDH}$ was increased by up to two- or threefold compared with the untreated group (Supplementary Figure 1b). Thus, $100 \mu \mathrm{M}$ $\mathrm{H}_{2} \mathrm{O}_{2}$ was chosen as the optimum effective dose and used in our subsequent studies.

Exposure of NIH3T3 cells to $100 \mu \mathrm{M} \mathrm{H}_{2} \mathrm{O}_{2}$ for $96 \mathrm{~h}$ resulted in a typical cellular senescence phenotype with an enlarged and flattened morphology (Figure 1a), and oxidative stressinduced growth arrest was assessed by cell counting (Figure 1b). Specialized domains of facultative heterochromatin, which are called senescence-associated heterochromatin foci (SAHF), are thought to contribute to the irreversible cell cycle exit in many senescent cells by repressing the expression of proliferation-promoting genes. ${ }^{29}$ In our model, SAHF appeared as compacted punctate foci of 4',6-diamidino-2-phenylindole (DAPI)-stained DNA in the enlarged nucleus of senescent cells after $\mathrm{H}_{2} \mathrm{O}_{2}$ treatment (Figure 1c). A senescence-specific marker is senescenceassociated $\beta$-galactosidase (SA- $\beta$-gal) activity, which is detectable by $\mathrm{X}$-gal staining at $\mathrm{pH}$ 6.0. The senescent cells exhibited positive SA- $\beta$-gal staining after $\mathrm{H}_{2} \mathrm{O}_{2}$ treatment (Figure 1d). The growth arrest of senescent cells was associated with the accumulation of several cell cycle regulatory genes, such as $\mathrm{p} 53$, which is also regarded as a hallmark of senescence. ${ }^{30}$ Thus, the upregulation of p53 was also showed in Figure 1e. Our results showed that the model of $\mathrm{H}_{2} \mathrm{O}_{2}$-induced premature senescence of NIH3T3 cells was established successfully. Cells treated with $\mathrm{H}_{2} \mathrm{O}_{2}$ for up to $96 \mathrm{~h}$ were harvested at different time points and analyzed for Zfp637 expression. Both the mRNA and protein expression levels of Zfp637 in cells were markedly decreased during cellular senescence (Figures $1 \mathrm{f}$ and $\mathrm{g}$ ). A similar senescence phenotype and repressed Zfp637 expression were observed in NIH3T3 cells treated with $8 \mathrm{~g} / \mathrm{l} \mathrm{D}$-gal for $96 \mathrm{~h}$ (Figures $1 \mathrm{a}-\mathrm{g}$ ) and in $\mathrm{C} 2 \mathrm{C} 12$ cells treated with $100 \mu \mathrm{M} \mathrm{H} \mathrm{H}_{2} \mathrm{O}_{2}$ for $96 \mathrm{~h}$ (Supplementary Figures $2 \mathrm{a}-\mathrm{g}$ ). These results suggest that Zfp637 may have a role in the regulation of cellular senescence.

Overexpression of Zfp637 protects cells against oxidative stress-induced premature senescence. To determine whether Zfp637 is involved in premature senescence, the Zfp637 expression plasmid (pcDNA3.1-Zfp637) was transfected into NIH3T3 cells, and significant increases in Zfp637 
a

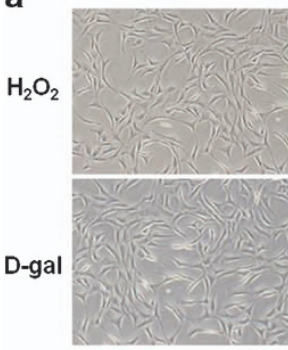

oh

c

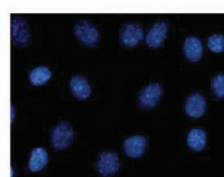

Control

d

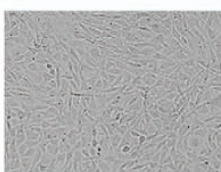

Control

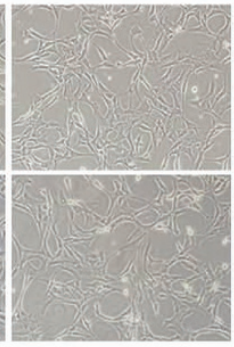

$24 \mathrm{~h}$

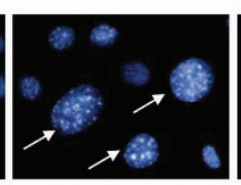

$\mathrm{H}_{2} \mathrm{O}_{2}$

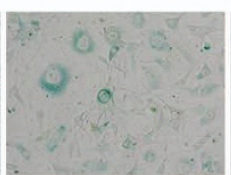

$\mathrm{H}_{2} \mathrm{O}_{2}$

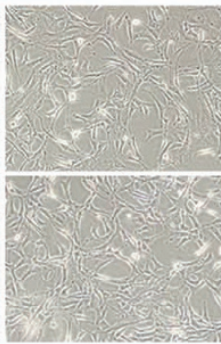

$48 \mathrm{~h}$

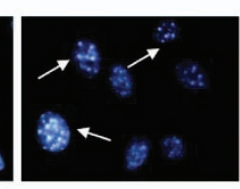

D-gal

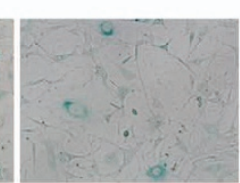

D-gal

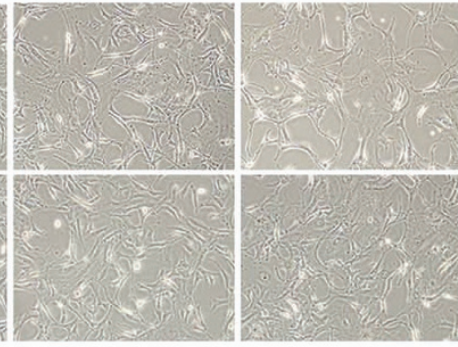

96h

e

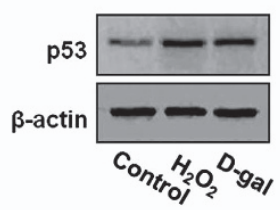

g

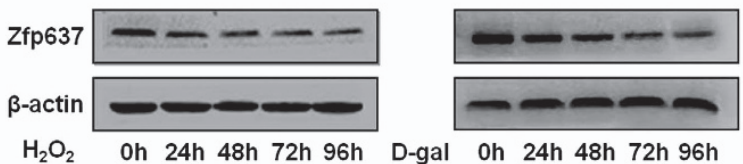

Figure 1 Zfp637 is downregulated during oxidative stress-induced premature senescence of $\mathrm{NIH} 3 \mathrm{~T} 3$ cells. $\mathrm{NIH} 3 \mathrm{~T} 3$ cells were cultured in medium containing $100 \mu \mathrm{M} \mathrm{H} \mathrm{H}_{2} \mathrm{O}_{2}$ or $8 \mathrm{~g} / \mathrm{l} \mathrm{D}$-gal for $96 \mathrm{~h}$. (a) Analysis of cellular morphology during cellular senescence induced by $\mathrm{H}_{2} \mathrm{O}_{2}$ and D-gal. (b) The cell proliferation curve was assessed by cell counting. (c) Representative images of senescence-associated heterochromatin foci (SAHF)-positive cells (indicated by the white arrows) determined by DAPI staining from three independent experiments. (d) Representative images of senescence-associated $\beta$-galactosidase (SA- $\beta$-gal)-positive cells from three independent experiments. (e) The p53 protein expression was analyzed by western blot. (f) Cells were harvested at the indicated time points after $\mathrm{H}_{2} \mathrm{O}_{2}$ or $\mathrm{D}$-gal exposure, and the Zfp637 mRNA expression was analyzed by qRT-PCR. (g) Cells were harvested at the indicated time points after $\mathrm{H}_{2} \mathrm{O}_{2}$ or D-gal exposure, and the Zfp637 protein expression was analyzed by western blot. All of the quantitative values are presented as the means \pm S.D. ${ }^{*} P<0.05$

mRNA and protein expression levels were detected (Figures $2 a$ and $b$ ). We utilized different sources to induce oxidative stress, including $\mathrm{H}_{2} \mathrm{O}_{2}$ and D-gal. The cell counting results showed that Zfp637 overexpression had no obvious effect on proliferation, but the growth arrest was attenuated during senescence induction (Figure 2c). In view of the known relationship between ROS accumulation and senescence, we tested whether Zfp637 upregulation affects ROS generation under oxidative stress. We found that senescent cells displayed higher intracellular ROS levels than normal cells, in agreement with previous reports. ${ }^{31}$ Zfp637 overexpression did not alter the basal intracellular ROS levels but reduced ROS accumulation upon $\mathrm{H}_{2} \mathrm{O}_{2}$ or D-gal treatment (Figure 2d). Senescence was assessed by the percentage of cells exhibiting SAHF and SA- $\beta$-gal activity. Cells overexpressing Zfp637 showed a reduction of SAHF-positive or SA- $\beta$-galpositive cells under $\mathrm{H}_{2} \mathrm{O}_{2}$-induced oxidative conditions compared with the control (from 64.07 to $22.05 \%$ or from 47.87 to $16.55 \%$, respectively; Figures $2 \mathrm{e}$ and f). Zfp637 overexpression displayed a similar role in preventing $\mathrm{D}$-galinduced senescence (Figures $2 e$ and $f$ ). To further examine the correlation between high expression of Zfp637 and senescence, cells were transfected with pEGFP-Zfp637 plasmid and senescence induction was performed. Subsequently, Zfp637 overexpression and SAHF were observed simultaneously. As shown in Supplementary Figure 3a, Zfp637 was located in the nucleus, and SAHF was not observed in the cells overexpressing Zfp637 upon oxidative stress, whereas SAHF was shown in cells transfected with pEGFP-N1 under the same conditions. Zfp637 overexpression also lessened the accumulation of p53 in both $\mathrm{H}_{2} \mathrm{O}_{2}$ and D-gal-induced senescent cells (Figure 2g). To exclude the possibility that the cells undergo apoptosis and necrosis upon $\mathrm{H}_{2} \mathrm{O}_{2}$ exposure, Annexin V-FITC-binding assay and $\mathrm{LDH}$ release assay were performed. The percentages of both apoptotic and necrotic cells were very low during senescence induction (Supplementary Figures $4 a$ and b). In addition, the percentage of senescent cells induced by $\mathrm{H}_{2} \mathrm{O}_{2}$ was also reduced in $\mathrm{C} 2 \mathrm{C} 12$ cells overexpressing Zfp637 (Supplementary Figures $3 b$ and $c$ ). These results indicate that Zfp637 can protect cells against premature senescence through attenuating the inhibition of proliferation and depressing ROS accumulation when cells suffer oxidative stress.

Knockdown of Zfp637 abrogates the protective effect against premature senescence. To further verify the protective role of endogenous Zfp637 against premature senescence, NIH3T3 cells were stably transfected with shRNA-Zfp637 or shRNA-negative control (shNC). The efficiency of Zfp637 knockdown with shRNA was confirmed (Figures $3 a$ and $b$ ). A slight inhibition of cellular proliferation was observed in NIH3T3-shRNA-zinc finger protein 637 (shZfp637) cells under conventional conditions. Moreover, Zfp637 depression enhanced the growth arrest induced by $\mathrm{H}_{2} \mathrm{O}_{2}$ and D-gal, and this effect was not observed in $\mathrm{NIH} 3 \mathrm{~T} 3$-shNC cells (Figure $3 \mathrm{c}$ ). As shown in Figure $3 \mathrm{~d}$, 


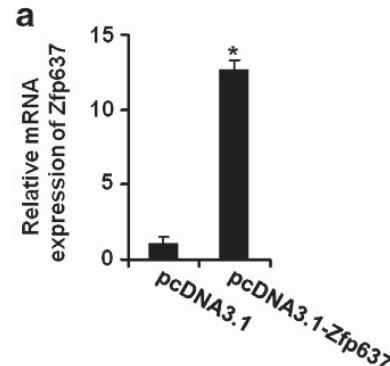

b
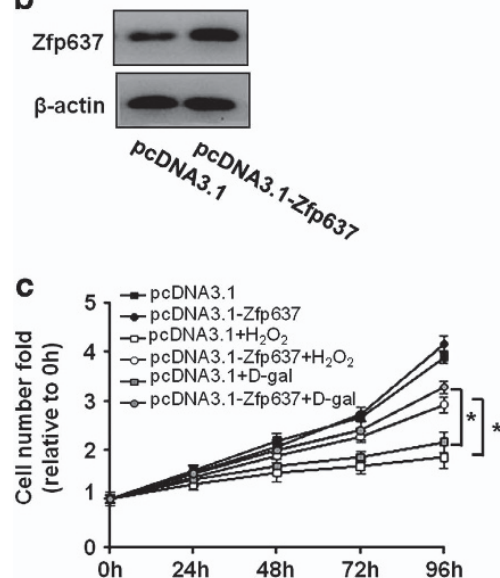

g

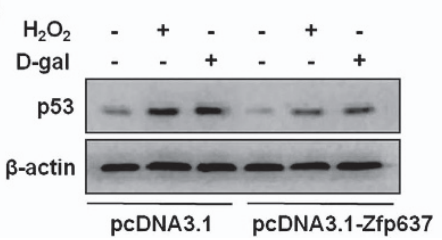

d

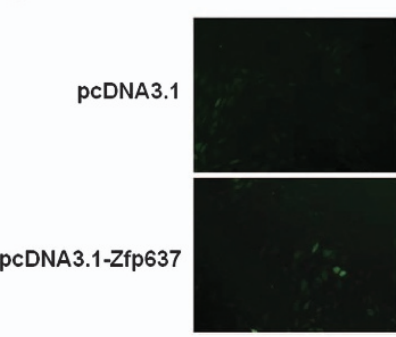

Control

e

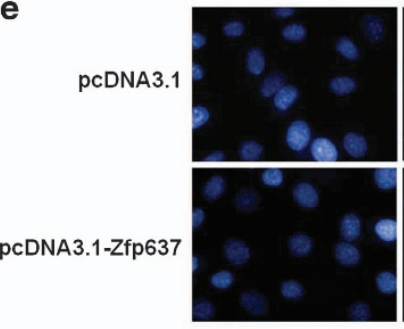

Control

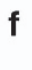

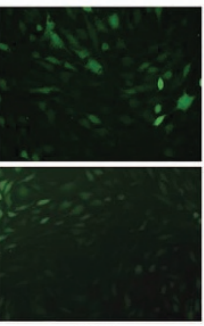

$\mathrm{H}_{2} \mathrm{O}_{2}$

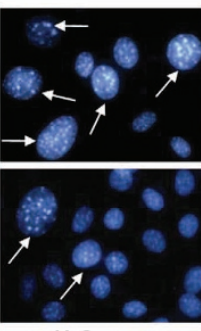

$\mathrm{H}_{2} \mathrm{O}_{2}$

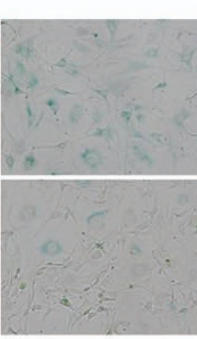

$\mathrm{H}_{2} \mathrm{O}_{2}$

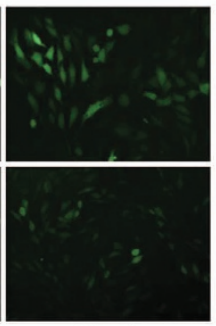

D-gal

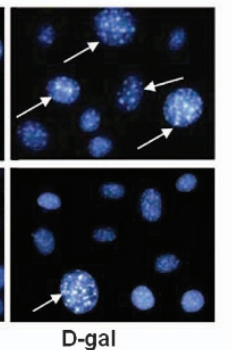

D-gal

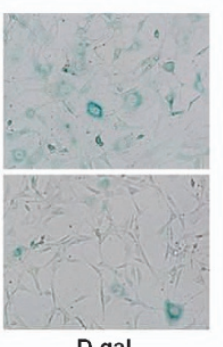

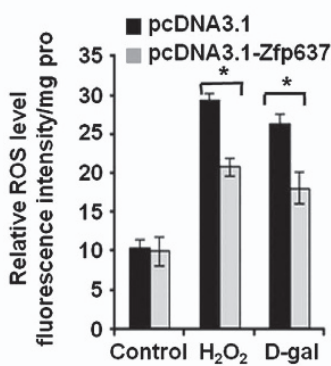

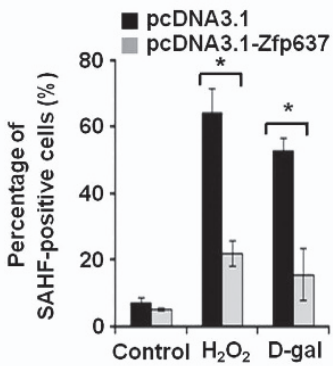

Figure 2 Zfp637 overexpression protects cells against oxidative stress-induced senescence. NIH3T3 cells were transfected with the pcDNA3.1-Zfp637 plasmid. Twentyfour hours post transfection, cells were treated with $100 \mu \mathrm{M} \mathrm{H}_{2} \mathrm{O}_{2}$ or $8 \mathrm{~g} / \mathrm{l}$ d-gal for $96 \mathrm{~h}$. (a) The Zfp637 mRNA expression was analyzed by qRT-PCR. (b) The Zfp637 protein expression was analyzed by western blot analysis. (c) The cell proliferation curve was assessed by cell counting. (d) The intracellular ROS level was detected by incubating with ROS-sensitive probe DCFH-DA for $30 \mathrm{~min}$. Left panel shows representative images of ROS fluorescence intensity from three independent experiments; right panel shows the relative fluorescence intensity, which was measured using a Fluoroskan Ascent FL. (e) SAHF was determined by DAPI staining. Left panel shows representative images of SAHF-positive cells (indicated by the white arrows) from three independent experiments; right panel shows the percentage of SAHF-positive cells, which was calculated from 10 fields of view under each condition. (f) SA- $\beta$-gal staining was performed. Left panel shows representative images of SA- $\beta$-gal-positive cells from three independent experiments; right panel shows the percentage of SA- $\beta$-gal-positive cells, which was calculated from 10 fields of view under each condition. (g) The p53 protein expression was analyzed by western blot analysis. All of the quantitative values are presented as the means \pm S.D. ${ }^{\star} P<0.05$

NIH3T3-shZfp637 cells exhibited no evident change in intracellular ROS production in the absence of $\mathrm{H}_{2} \mathrm{O}_{2}$ or D-gal, whereas a remarkable elevation of ROS level occurred in response to oxidative stress (Figure 3d). Zfp637 knockdown did not result in cell senescence directly but rather abrogated the protective effect of this protein against oxidative stress. As a consequence, a pro-senescence effect was observed in NIH3T3-shZfp637 cells after exposure to $\mathrm{H}_{2} \mathrm{O}_{2}$ or D-gal because a higher proportion of SAHF-positive cells was obtained compared with that observed in NIH3T3shNC cells (Figure 3e). Consistently, approximately 90 or $80 \%$ NIH3T3-shZfp637 cells exhibited positive SA- $\beta$-gal staining accompanied by senescence-specific morphological changes upon $\mathrm{H}_{2} \mathrm{O}_{2}$ or D-gal treatment, respectively (Figure 3f). The expression of p53 was increased significantly in senescent Zfp637-deficient cells compared with senescent shNC cells (Figure $3 \mathrm{~g}$ ). In addition, only a small proportion of cells underwent apoptosis or necrosis upon $\mathrm{H}_{2} \mathrm{O}_{2}$ treatment (Supplementary Figures $4 \mathrm{a}$ and b). Cellular senescence was also aggravated in C2C12-shZfp637 cells treated with $\mathrm{H}_{2} \mathrm{O}_{2}$ (Supplementary Figures $3 \mathrm{~b}$ and $\mathrm{c}$ ). These findings demonstrate that the loss of Zfp637 may aggravate oxidative stress-induced premature senescence because of increased susceptibility to ROS.

Protective role of Zfp637 against oxidative stress-induced premature senescence depends on mTERT. A previous study noted that accelerated telomere shortening is observed after oxidative stress. ${ }^{32}$ We showed that the relative ratio of telomeres to a single-copy gene (36B4) (T/S) was reduced in $\mathrm{H}_{2} \mathrm{O}_{2}$ - and D-gal-induced senescent cells by quantitative realtime PCR (qRT-PCR), as previously described (Table 1). ${ }^{33,34}$ 


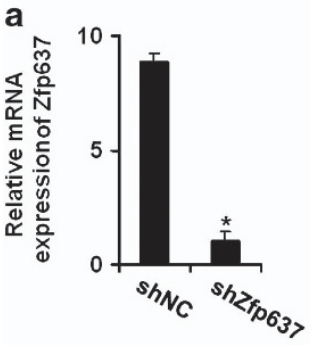

b
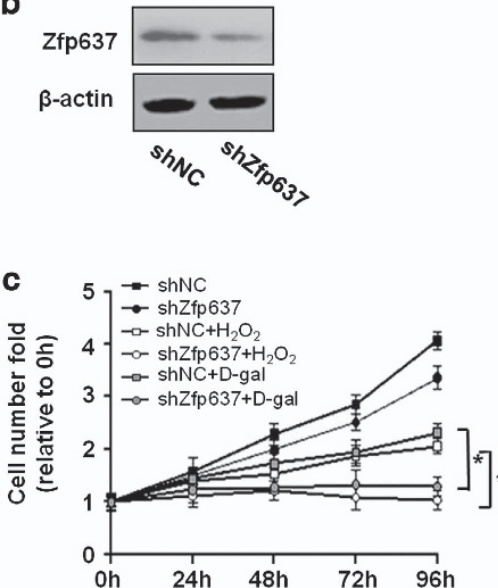

g

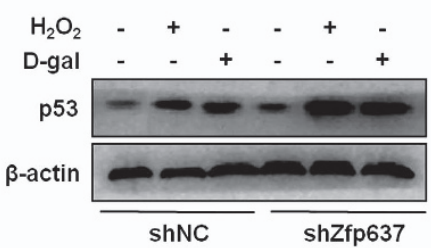

d

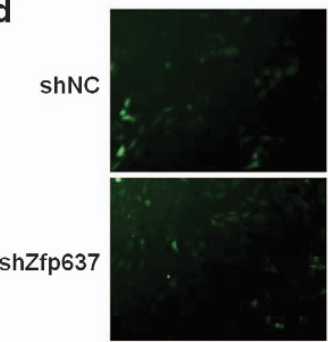

Control

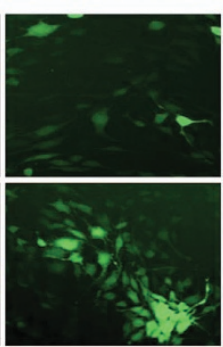

$\mathrm{H}_{2} \mathrm{O}_{2}$

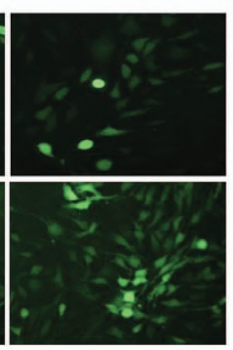

D-gal

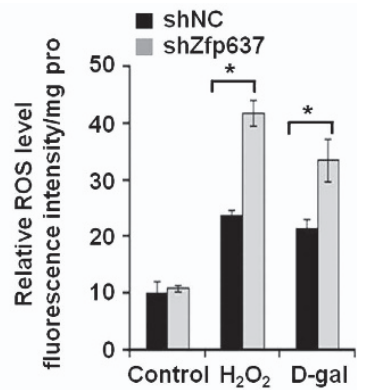

e
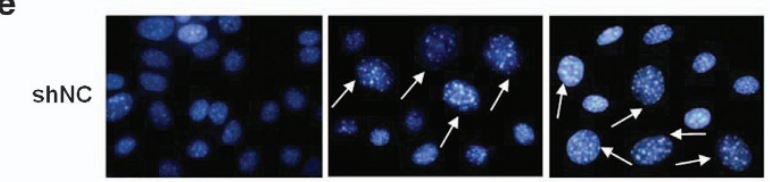

shZfp637

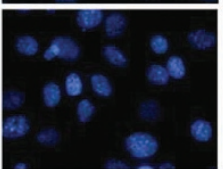

Control

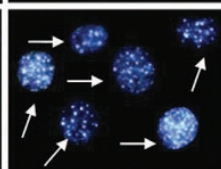

$\mathrm{H}_{2} \mathrm{O}_{2}$

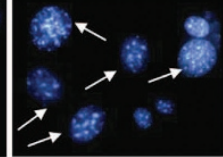

D-gal

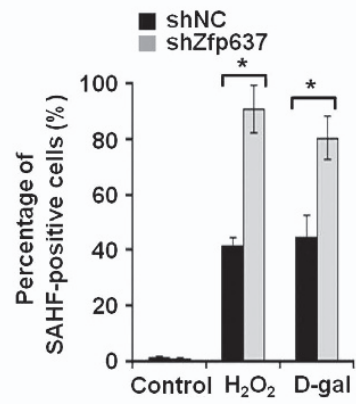

f

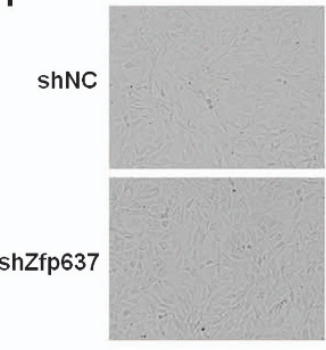

Control

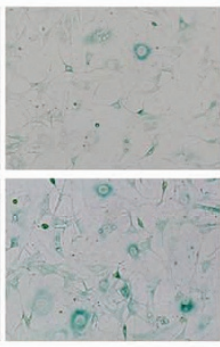

$\mathrm{H}_{2} \mathrm{O}_{2}$

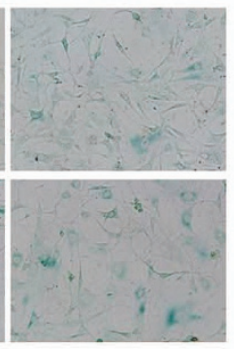

D-gal

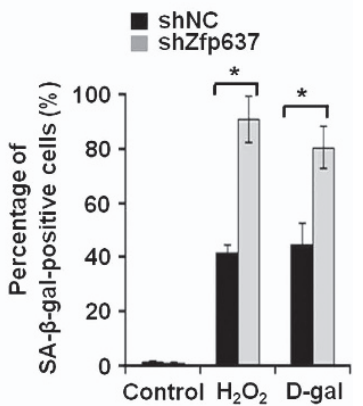

Figure 3 Zfp637 knockdown aggravates oxidative stress-induced senescence. NIH3T3 cells were stably transfected with shRNA-Zfp637 and treated with $100 \mu \mathrm{M} \mathrm{H} \mathrm{H}_{2} \mathrm{O}_{2}$ or $8 \mathrm{~g} / \mathrm{l}$-gal for $96 \mathrm{~h}$. (a) The Zfp637 mRNA expression was analyzed by qRT-PCR. (b) The Zfp637 protein expression was analyzed by western blot analysis. (c) The cell proliferation curve was assessed by cell counting. (d) The intracellular ROS level was detected by incubating with ROS-sensitive probe DCFH-DA for 30 min. Left panel shows representative images of ROS fluorescence intensity from four independent experiments; right panel shows the relative fluorescence intensity, which was measured using a Fluoroskan Ascent FL. (e) SAHF was determined by DAPI staining. Left panel shows representative images of SAHF-positive cells (indicated by the white arrows) from four independent experiments; right panel shows the percentage of SAHF-positive cells, which was calculated from 10 fields of view under each condition. (f) SA- $\beta$-gal staining was performed. Left panel shows representative images of SA- $\beta$-gal-positive cells from four independent experiments; right panel shows the percentage of SA- $\beta$-gal-positive cells, which was calculated from 10 fields of view under each condition. (g) The p53 protein expression was analyzed by western blot analysis. All of the quantitative values are presented as the means \pm S.D. ${ }^{*} P<0.05$

It has been acknowledged that the decrease in the relative T/S ratio positively correlates with telomere shortening. ${ }^{33,34}$ TERT is indispensable in maintaining telomerase activity and telomere length in tissues and immortal cells. ${ }^{35}$ Therefore, we detected mTERT expression and telomerase activity during NIH3T3 cellular senescence. Coincidently, both mTERT expression (at the mRNA and protein levels) and telomerase activity were gradually decreased in $\mathrm{H}_{2} \mathrm{O}_{2}$ - or D-gal-induced premature senescence (Supplementary Figures $5 \mathrm{a}-\mathrm{c}$ ). Consistent with previous reports, ${ }^{36}$ these results imply that the downregulation of mTERT mediates a decrease in telomerase activity in cellular senescence. Interestingly, the downregulation of Zfp637 was earlier than that of mTERT and telomerase activity, suggesting that an interrelation between mTERT and Zfp637 may exist during oxidative stress-induced premature senescence. The correlation between Zfp637 and mTERT was also confirmed during senescence induction of $\mathrm{C} 2 \mathrm{C} 12$ cells (Supplementary Figures $2 \mathrm{e}$ and $\mathrm{g}$ ).

Considering the potential correlation between Zfp637 and mTERT, we analyzed mTERT expression and telomerase activity in NIH3T3-shZfp637 cells undergoing senescence. Zfp637 knockdown decreased mTERT expression and telomerase activity slightly, whereas these were sharply reduced in $\mathrm{H}_{2} \mathrm{O}_{2}$ - or D-gal-induced senescent NIH3T3shZfp637 cells (Figures $4 a$ and b). To illuminate whether the protective effect of Zfp637 against premature senescence is dependent on the regulation of $\mathrm{mTERT}$, we analyzed mTERT expression and telomerase activity in NIH3T3 cells overexpressing Zfp637 in the presence of $\mathrm{H}_{2} \mathrm{O}_{2}$ or D-gal. 
As shown in Figures $4 \mathrm{a}$ and b, Zfp637 overexpression resulted in the upregulation of mTERT expression and telomerase activity under both conventional and oxidative stress conditions. We also demonstrated that Zfp637 overexpression maintained a higher relative T/S ratio in $\mathrm{H}_{2} \mathrm{O}_{2}$ - or $\mathrm{D}$-gal-treated cells (Table 1 ). In contrast, the relative $\mathrm{T} / \mathrm{S}$ ratio was decreased significantly in NIH3T3-shZfp637 cells compared with NIH3T3-shNC cells as a result of oxidative stress (Table 1). Our results indicate that Zfp637 overexpression contributes to the maintenance of stable telomere length, but Zfp637 deletion accelerates telomere shortening in senescence induction by oxidative stress. Zfp637 overexpression exerted similar effects on mTERT expression, telomerase activity, and telomere length in $\mathrm{H}_{2} \mathrm{O}_{2}$-induced senescence of $\mathrm{C} 2 \mathrm{C} 12$ cells. On the contrary, the opposite effects were observed in C2C12-shZfp637 cells compared with $\mathrm{C} 2 \mathrm{C} 12$ cells overexpressing Zfp637 (Supplementary Figures 5d and e and Supplementary Table 1).

Furthermore, the co-transfection with small interfering RNA (siRNA)-mTERT and pcDNA3.1-Zfp637 was performed in NIH3T3 cells. The Zfp637-mediated increase in mTERT expression and telomerase activity under oxidative stress was abrogated by the silencing of mTERT (Figures $4 \mathrm{c}$ and d). mTERT inhibition also weakened the anti-senescence capacity of Zfp637 overexpression, as judged by the higher

Table 1 Relative telomere length ratio and standard deviation calculated for NIH3T3 cells

\begin{tabular}{lll}
\hline Group & $\begin{array}{c}\text { Relative telomere length ratio } \\
\text { (mean } \pm \text { S.D.) }\end{array}$ \\
\hline 1 & Control & $1.674 \pm 0.115$ \\
2 & $\mathrm{H}_{2} \mathrm{O}_{2}$ & $1.010 \pm 0.031^{*, \mathrm{a}}$ \\
3 & $\mathrm{D}-$ gal & $1.059 \pm 0.091^{*, \mathrm{a}}$ \\
4 & pcDNA3.1 & $1.587 \pm 0.064$ \\
5 & pcDNA3.1-Zfp637 & $1.626 \pm 0.087$ \\
6 & pcDNA3.1 $+\mathrm{H}_{2} \mathrm{O}_{2}$ & $0.916 \pm 0.031$ \\
7 & pcDNA3.1-Zfp637 $+\mathrm{H}_{2} \mathrm{O}_{2}$ & $1.262 \pm 0.068^{*, \mathrm{~b}}$ \\
8 & pcDNA3.1 $+\mathrm{D}-\mathrm{gal}$ & $1.017 \pm 0.077$ \\
9 & pcDNA3.1-Zfp637 $+\mathrm{D}-\mathrm{gal}$ & $1.376 \pm 0.050^{\star, \mathrm{c}}$ \\
10 & shNC & $1.607 \pm 0.161$ \\
11 & shZfp637 & $1.634 \pm 0.072$ \\
12 & shNC $+\mathrm{H}_{2} \mathrm{O}_{2}$ & $0.981 \pm 0.119$ \\
13 & shZfp637 $+\mathrm{H}_{2} \mathrm{O}_{2}$ & $0.645 \pm 0.043^{*, \mathrm{~d}}$ \\
14 & shNC $+\mathrm{D}-\mathrm{gal}$ & $1.069 \pm 0.074$ \\
15 & shzfp637 $+\mathrm{D}-\mathrm{gal}$ & $0.725 \pm 0.099^{*, \mathrm{e}}$ \\
\end{tabular}

Abbreviations: D-gal, D-galactose; Zfp637, zinc finger protein 637

${ }^{*} P<0.05$

${ }^{\mathrm{a} C}$ Compare with group 1

${ }^{\mathrm{b}} \mathrm{Compare}$ with group 6

${ }^{\mathrm{c} C o m p a r e ~ w i t h ~ g r o u p ~} 8$

${ }^{\mathrm{d} C o m p a r e}$ with group 12

${ }^{\mathrm{e}}$ Compare with group 14 percentage of SAHF-positive and SA- $\beta$-gal-positive cells and the accumulation of p53 protein (Figures $4 \mathrm{e}-\mathrm{g}$ ). Taken together, our results suggest that the protective effect of Zfp637 against oxidative stress-induced premature senescence is mTERT-dependent.

Zfp637 exerts an mTERT-dependent anti-senescence effect through binding and transactivating the mTERT promoter. To understand the mechanism underlying how mTERT expression responds to oxidative stress, we attempted to analyze the mTERT promoter. An approximately $1.0-\mathrm{kb}$ section upstream of the mTERT gene-coding region was isolated (Figure $5 \mathrm{a}$ ), and luciferase reporter vectors containing mTERT promoter fragments with various lengths were generated by inserting the PCR-amplified DNA fragment into the pGL3-basic vector. As shown in Supplementary Figure $6 \mathrm{a}$, the transcriptional activity of the mTERT promoter $(-535 /+53)$ was decreased notably in cells exposed to $\mathrm{H}_{2} \mathrm{O}_{2}$ or D-gal. Oxidative stress also induced a slight decrease in transcriptional activity of the mTERT promoter $(-1024 /+53)$. In contrast, the other mTERT promoter regions displayed no depression of transcriptional activity in response to oxidative stress. To clarify whether the transcriptional activation of mTERT is regulated by Zfp637, NIH3T3 cells were co-transfected with the pGL3-mTERT promoter $(-535 /+53)$ and pcDNA3.1-Zfp637, and then subjected to $\mathrm{H}_{2} \mathrm{O}_{2}$ or D-gal treatment. Zfp637 overexpression resulted in an approximately twofold increase in mTERT transcriptional activity, and the oxidative stress-induced depression of transcriptional activity was partially rescued (Figure 5b). These results suggest that Zfp637 likely binds to the region within the mTERT promoter $(-535 /-399)$. As the sequence of Zfp637-binding site has never been reported, pGL3-mTERT promoter $(-535 /+53)$ plasmids with various lengths of a $5^{\prime}$-terminus-truncated mutant were constructed. The deletion of DNA fragment $(-535 /-502)$ blocked the Zfp637-mediated upregulation of MTERT transcriptional activity (Figure $5 \mathrm{c}$ ), indicating that the region within the mTERT promoter $(-535 /-502)$ may contain the potential Zfp637-binding site.

Subsequently, electrophoretic mobility shift assay (EMSA) was performed to verify whether Zfp637 directly and specifically binds to the oxidative stress-responsive mTERT promoter. A GST-Zfp637 fusion protein was constructed and purified as described in our previous report. ${ }^{28}$ We demonstrated that the GST-Zfp637 fusion protein formed complexes with a probe derived from the MTERT promoter ( - 535/ - 502; Supplementary Figure $6 \mathrm{~b}$ ). EMSA also revealed that nuclear extracts from NIH3T3-shNC cells interacted with the

Figure 4 The protective effect of Zfp637 against oxidative stress-induced premature senescence depends on mTERT. NIH3T3-shZfp637 cells were treated with $100 \mu \mathrm{M}$ $\mathrm{H}_{2} \mathrm{O}_{2}$ or $8 \mathrm{~g} / \mathrm{l}$-gal for $96 \mathrm{~h}$ (a and b, left panels). NIH3T3 cells were transfected with the pcDNA3.1-Zfp637, and $24 \mathrm{~h}$ post transfection, the cells were treated with $100 \mu \mathrm{M} \mathrm{H} \mathrm{H}_{2} \mathrm{O}_{2}$ or $8 \mathrm{~g} / \mathrm{l}$-gal for $96 \mathrm{~h}$ ( $\mathbf{a}$ and $\mathbf{b}$, right panels). (a) The Zfp637 and mTERT protein expression was analyzed by western blot analysis. (b) PCR-ELISA was used to measure the telomerase activity. NIH3T3 cells were co-transfected with the pcDNA3.1-Zfp637 and siRNA-mTERT, and $24 \mathrm{~h}$ post transfection, the cells were treated with $100 \mu \mathrm{M} \mathrm{H}_{2} \mathrm{O}_{2}$ or $8 \mathrm{~g} / \mathrm{l} \mathrm{D}$-gal for $96 \mathrm{~h} \mathrm{(c,} \mathrm{d,} \mathrm{e,} \mathrm{and} \mathrm{f).} \mathrm{(c)} \mathrm{The} \mathrm{Zfp637} \mathrm{and} \mathrm{mTERT} \mathrm{protein} \mathrm{expression} \mathrm{was} \mathrm{analyzed} \mathrm{by} \mathrm{western} \mathrm{blot} \mathrm{analysis.} \mathrm{(d)} \mathrm{PCR-ELISA} \mathrm{was} \mathrm{used} \mathrm{to} \mathrm{measure} \mathrm{the} \mathrm{telomerase}$ activity. (e) SAHF was determined by DAPI staining. Left panel shows representative images of SAHF-positive cells (indicated by the white arrows) from three independent experiments; right panel shows the percentage of SAHF-positive cells, which was calculated from 10 fields of view under each condition. (f) $S A$ - $\beta$-gal staining was performed. Left panel shows representative images of $S A$ - $\beta$-gal-positive cells from three independent experiments; right panel shows the percentage of $S A-\beta$-gal-positive cells, which was calculated from 10 fields of view under each condition. $(\mathbf{g})$ The p53 protein expression was analyzed by western blot. All of the quantitative values are presented as the means \pm S.D. ${ }^{*} P<0.05$ 
probe derived from the mTERT promoter and formed Zfp637/ DNA complexes, which were decreased in $\mathrm{H}_{2} \mathrm{O}_{2}$ - or D-galinduced senescent cells. However, the interaction of Zfp637
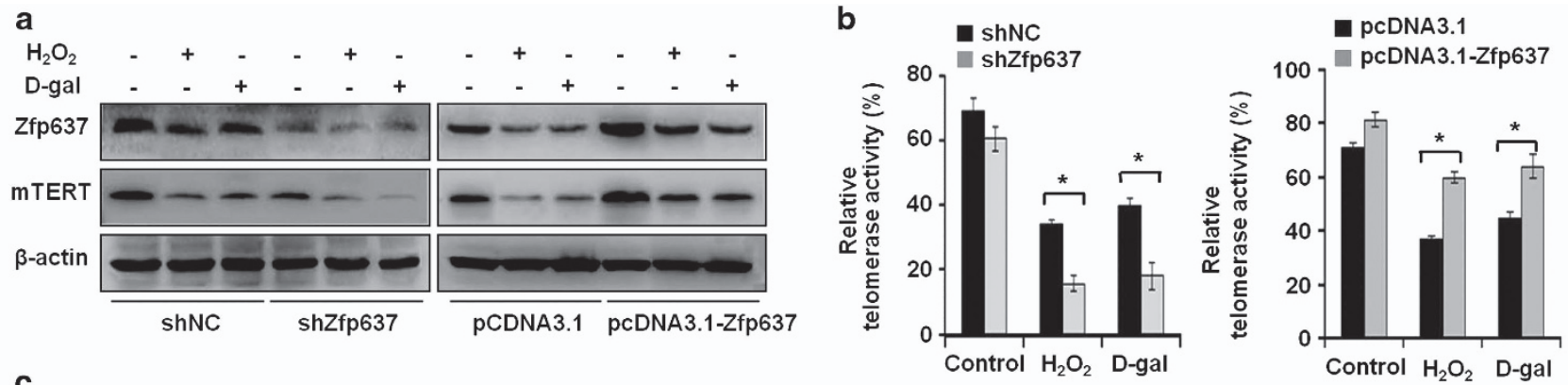

C
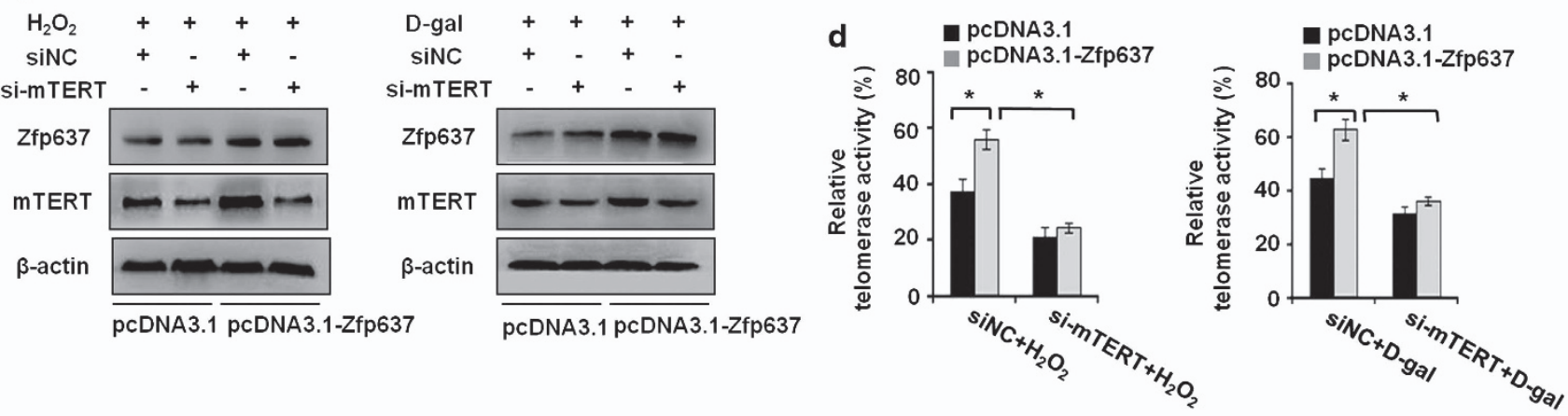

e

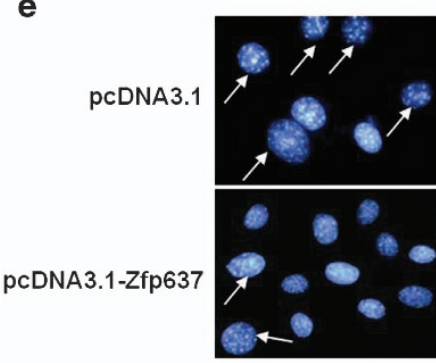

$\mathrm{SiNC}+\mathrm{H}_{2} \mathrm{O}_{2}$

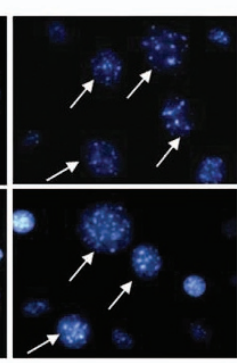

si-mTERT $+\mathrm{H}_{2} \mathrm{O}_{2}$

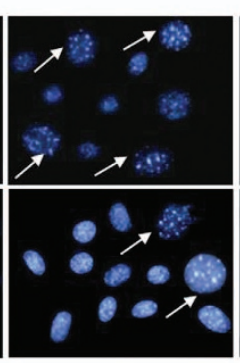

siNC+D-gal

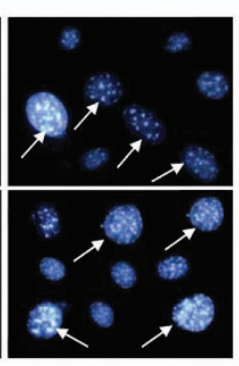

si-mTERT+D-gal
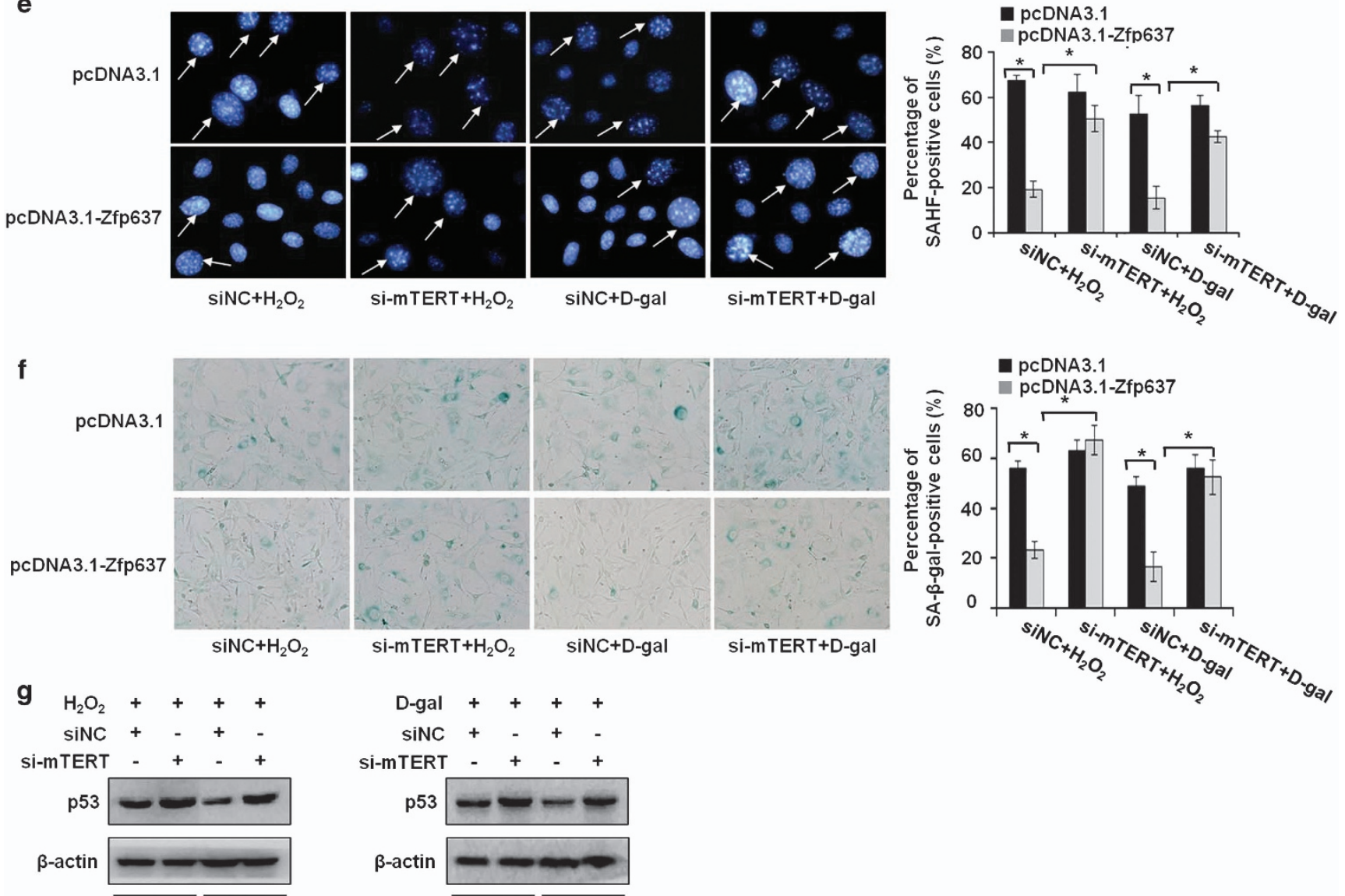

pcDNA3.1 pcDNA3.1-Zfp637 and the mTERT promoter $(-535 /-502)$ was significantly weakened in NIH3T3-shZfp637 cells, and Zfp637 knockdown further prevented complex formation under oxidative stress 
a

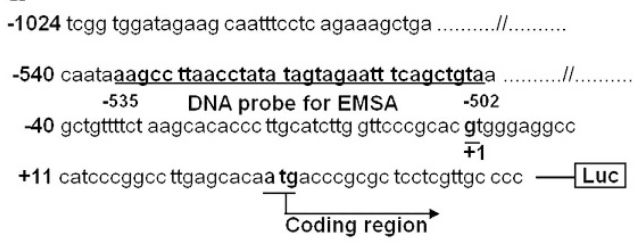

b

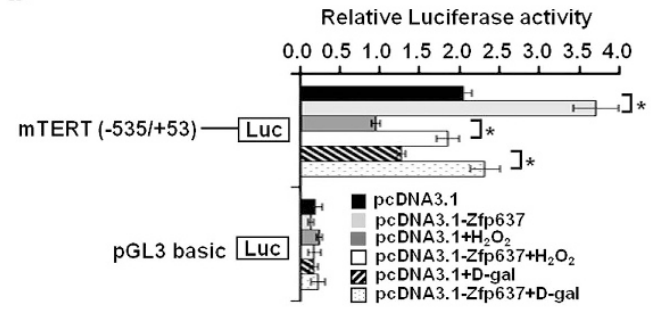

C

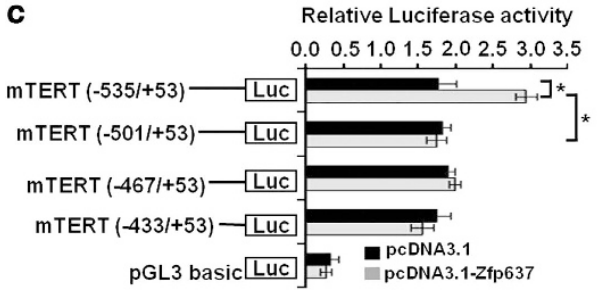

d

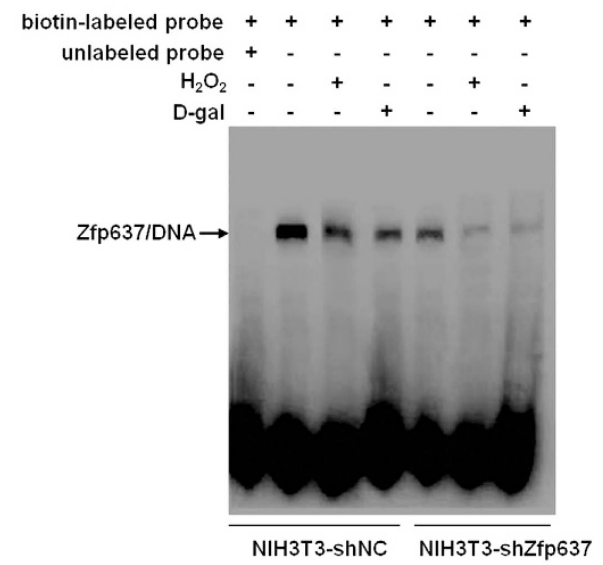

Figure 5 Zfp637 exerts an mTERT-dependent anti-senescence effect through binding to and transactivating the mTERT promoter. (a) Construct linking the $5^{\prime}$-proximal regulator region of the mTERT promoter to the luciferase reporter gene. The oligonucleotides used in EMSA are underlined. The transcription start site is indicated by +1 , and the initiation codon ATG is shown in bold. (b) The cells were co-transfected with the pcDNA3.1-Zfp637 plasmid and a pGL3-mTERT promoter construct $(-535 /+53)$. Twenty-four hours post transfection, the cells were treated with $100 \mu \mathrm{M} \mathrm{H}_{2} \mathrm{O}_{2}$ or $8 \mathrm{~g} / \mathrm{l}$-gal for $96 \mathrm{~h}$ and the luciferase activity was then measured. (c) The cells were cotransfected with the pcDNA3.1-Zfp637 plasmid and pGL3-mTERT promoter depletion-mutant constructs. Forty-eight hours post transfection, the luciferase activity was measured. (d) EMSA was performed with the nuclear extracts from NIH3T3 cells that are stably transfected with shNC or shRNA-Zfp637, and untreated or treated with $100 \mu \mathrm{M}$ $\mathrm{H}_{2} \mathrm{O}_{2}$ or $8 \mathrm{~g} / \mathrm{l}$-gal for $96 \mathrm{~h}$. The nuclear extracts were incubated with mTERT $(-535 /-502)$ biotin-labeled oligonucleotides in the presence or absence of unlabeled doublestranded probes. The arrows indicate the specific complexes. All of the quantitative values are presented as the means \pm S.D. ${ }^{*} P<0.05$

conditions (Figure $5 d$ ). In brief, these results are consistent with the direct binding of Zfp637 to the mTERT promoter leading to a major anti-senescence effect through transcriptional transactivation of mTERT.

Decreased Zfp637 expression inhibits mTERT-mediated telomerase activity in aged BALB/C mice. It has been proposed that normal aging results from random deleterious damage to tissue by oxidative stress caused by ROS. ${ }^{37}$ The reconstitution of telomerase activity in vivo leads to an increase in telomere length and an extension of cellular life span. $^{38}$ To demonstrate the correlation between Zfp637 and mTERT during aging in vivo, the mRNA expression of Zfp637 was first analyzed in organ tissues from 8-week-old and 10month-old male BALB/C mice. Zfp637 expression was decreased in the blood vessel, cerebellum, kidney, lung, spleen, and testicle tissues from aged mice (Figure 6a). Coincidently, extensive SA- $\beta$-gal-positive staining was observed in all of these tissues with the exception of blood vessels (Figure 6b). Zfp637 expression was not downregulated in other tissues, which were negative for SA- $\beta$ gal staining (Figures $6 a$ and $b$ ). It was further demonstrated that the protein expression of Zfp637 and mTERT was markedly decreased in most senescent tissues with the exception of blood vessels (Figure 6c). We also observed increased ROS production and decreased telomerase activity in senescent tissues from aged individuals (Figures $6 \mathrm{~d}$ and e). As the telomere length differs between tissues in an adult mouse, ${ }^{39}$ the Zfp637-mediated regulation of mouse telomerase activity may be tissue specific during development and aging in vivo. Taken together, our results indicate that Zfp637 repression may contribute to aging by inhibiting mTERT-mediated telomerase activity.

\section{Discussion}

A number of zinc finger proteins have been shown to have critical roles in cellular proliferation, differentiation, and senescence. OsDOS, a nuclear-localized zinc finger protein, has a role in delaying leaf senescence in rice. ${ }^{40}$ Transforming growth factor $\beta 1$-inducible hic- 5 gene encodes a putative zinc finger protein that is associated with cellular senescence. ${ }^{41}$ Our previous investigation demonstrated that Zfp637 promotes myogenic cellular proliferation and inhibits cellular differentiation by upregulating mTERT. ${ }^{24}$ However, the mechanism underlying the regulation of mTERT by Zfp637 has not been previously elucidated. In this study, we focused on the relationship between Zfp637 and mTERT in the model of oxidative stress-induced premature senescence.

Cells undergoing stress-induced premature senescence manifest all the characteristics of replicatively senescent cells: an enlarged and flattened morphology, SA- $\beta$-gal activity, 
a

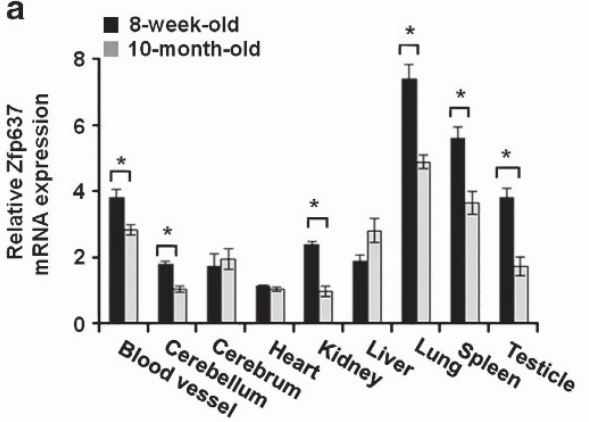

d

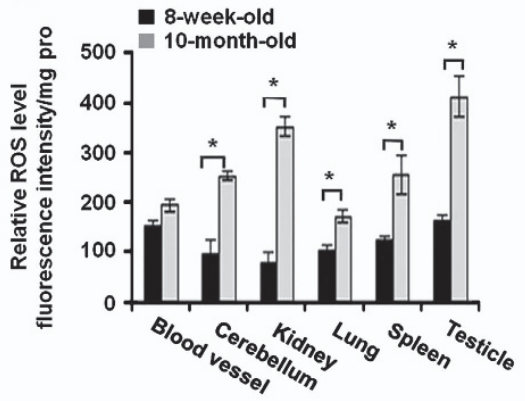

b

Cerebellum

Kidney

Lung

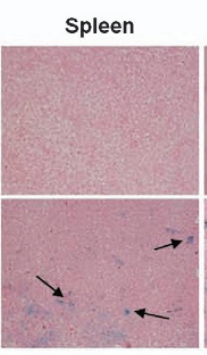

Testicle
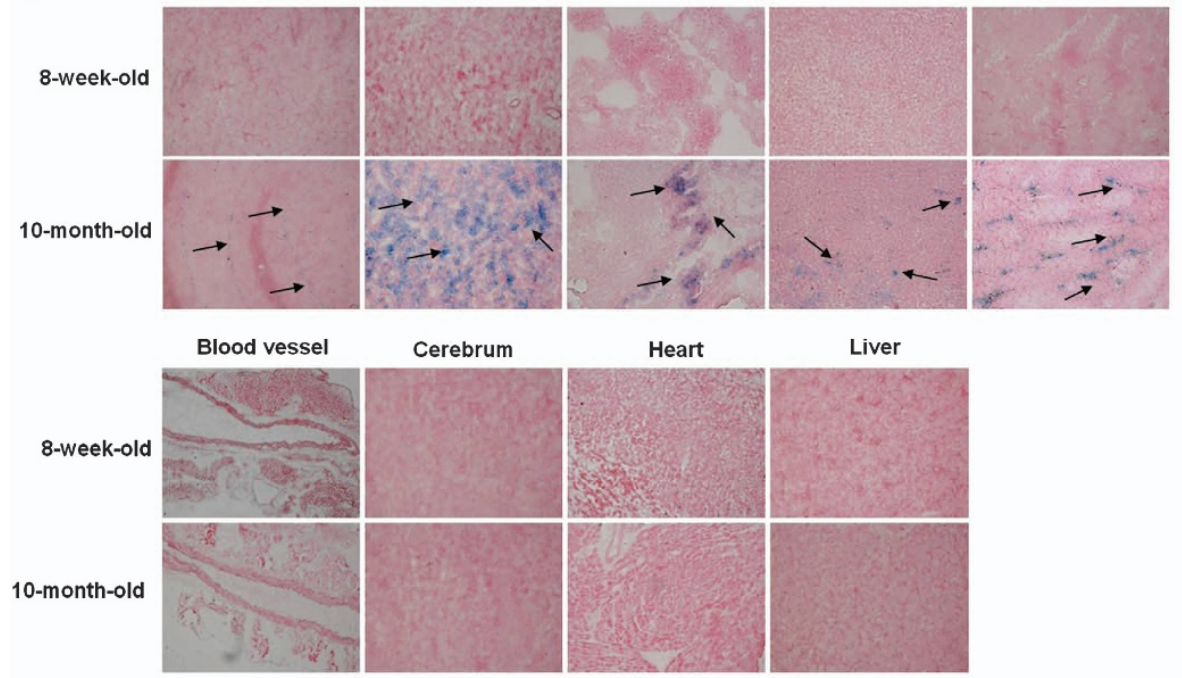

Cerebrum

Heart

C

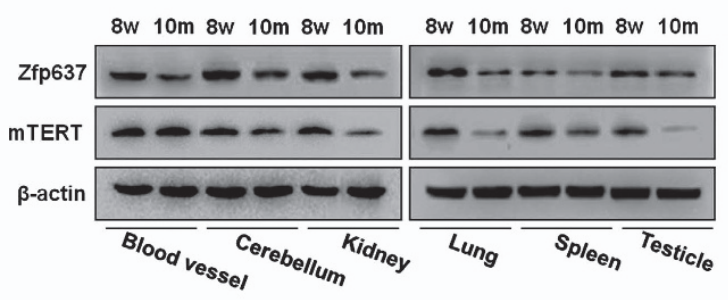

Liver

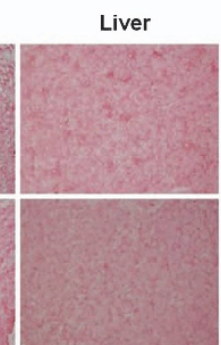

e

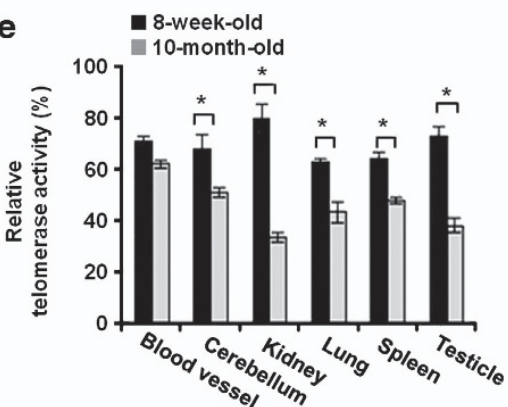

Figure 6 Decreased Zfp637 expression inhibits mTERT-mediated telomerase activity in aged BALB/C mice. The 8-week-old and 10-month-old male BALB/C mice were killed, and the blood vessel, cerebellum, cerebrum, heart, kidney, liver, lung, spleen, and testicle tissues were collected. (a) The Zfp637 mRNA expression was analyzed by qRT-PCR. (b) Representative images of tissue sections showed SA- $\beta$-gal staining from five independent experiments. The frozen sections of tissues (blood vessel, cerebellum, cerebrum, heart, kidney, liver, lung, spleen, and testicle) from mice were subjected to SA- $\beta$-gal staining and then counterstained with eosin. (c) The Zfp637 and mTERT protein expression were analyzed by western blot analysis. (d) The relative ROS levels in tissues from young/aged BALB/C mice were detected by incubating with ROS-sensitive probe DCFH-DA. (e) PCR-ELISA was used to measure the telomerase activity in tissues from young/aged BALB/C mice. All of the quantitative values are presented as the mean \pm S.D. ${ }^{*} P<0.05$

SAHF formation, cell cycle regulation, gene expression, and telomere shortening. The intensity of SAHF formation was shown to be different depending on the senescence stimulus and the cell type. ${ }^{42}$ Primary mouse fibroblasts, prepared from pooled wild-type C57BL/6J embryos and ear skin, did not form robust punctate SAHF in response to an activated Ras oncogene. ${ }^{43}$ Potential differences between primary cells and immortalized cell lines are likely to exist. In our study, only a small minority of proliferating NIH3T3 cells displayed a few punctate DAPI-stained domains, but discernible change was observed in senescent cells with larger cell nucleus and clearly visible domains of bright DAPI-stained heterochromatin.

The overexpression of antioxidant protein in fibroblasts slows the rate of telomere shortening and extends their life span. ${ }^{44}$ Accelerated telomere shortening caused by oxidative stress has been suggested as a cause of stress-induced premature senescence. ${ }^{45,46}$ Telomerase is essential for the maintenance of telomere length in cells. ${ }^{16}$ An important regulatory factor for telomerase is at the level of expression 


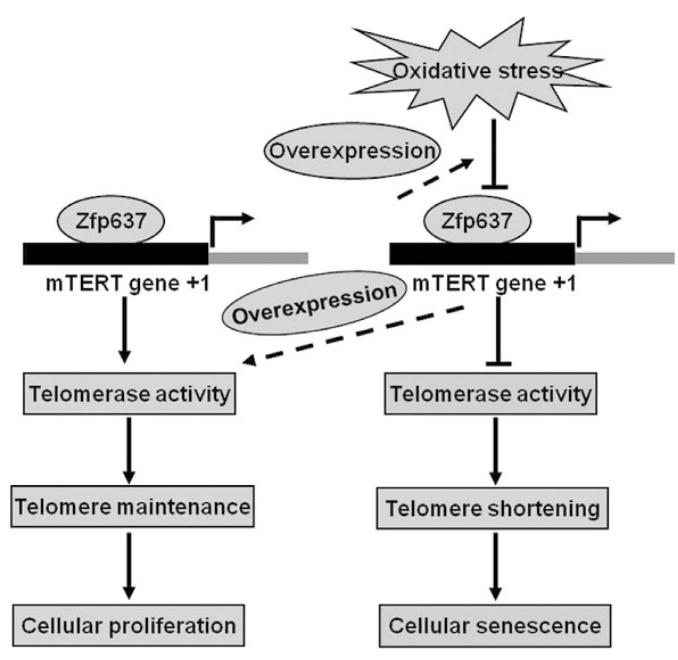

Figure 7 Schematic diagram summarizing that the protective effect of Zfp637 against oxidative stress-induced premature senescence depends on mTERTmediated telomerase activity and telomere maintenance. The downregulation of Zfp637 in cells suffering oxidative stress results in the depressed binding of Zfp637 to the mTERT promoter. Thus, the mTERT-dependent telomerase activity is reduced and the cells enter a senescent state accompanied with telomere shortening. Zfp637 overexpression prevents oxidative stress-induced premature senescence by rescuing telomerase activity and maintaining telomere length

of the TERT subunit, which is the major determinant of telomerase activity. TERT overexpression counteracts telomere shortening, extends the replicative potential, and prevents senescence. ${ }^{47}$ TERT not only maintains telomere length under standard conditions but also protects human fibroblasts against oxidative stress. ${ }^{48}$ In addition, TERT overexpression reduces mitochondrial DNA damage levels under oxidative stress and improves mitochondrial function, resulting in a lower mitochondrial production of ROS and an enhanced mitochondrial membrane potential. ${ }^{48}$

In this study, we clearly demonstrated that the expression Zfp637 and mTERT was decreased during cellular senescence, and that both telomerase activity and telomere length were also reduced. In addition, Zfp637 overexpression strongly reduced the accumulation of ROS and the proportion of senescent cells by promoting cell proliferation vitality under oxidative stress. In contrast, Zfp637 knockdown exhibited the converse effects. Furthermore, Zfp637 knockdown resulted in the attenuation of mTERT expression and telomerase activity, and this effect was aggravated during oxidative stressinduced senescence. Accelerated telomere shortening was also observed in Zfp637-deficient cells under oxidative stress. These results indicate that Zfp637 is closely associated with mTERT expression, telomerase activity, and telomere length in both proliferating and senescent cells. We also proved that mTERT knockdown diminished the anti-senescence effect of Zfp637, indicating that the protective effect of Zfp637 against oxidative stress-induced senescence depends on mTERTmediated telomere maintenance and stress resistance.

Oxidative stress is also believed to be a primary factor in the normal process of aging. ${ }^{49}$ Our study showed that both Zfp637 and mTERT were downregulated consistently in senescent tissues from naturally aged mice, and this downregulation was accompanied by increased ROS production.
These results provide a foundation for investigating the precise role of Zfp637 during development and aging in vivo.

The regulation of TERT involves transcriptional and posttranscriptional mechanisms. The transcriptional regulation of TERT is predominantly implicated in the regulation of telomerase activity in cells. ${ }^{50}$ The upstream region of the translational start site of TERT contains several types of transcriptional regulatory elements, such as GC box and $\mathrm{E}$ box, indicating that various transcription factors, including Sp1, Sp3, and Myc, can activate TERT expression by binding to the TERT promoter. ${ }^{51}$ In a previous report, we hypothesized that Zfp637 may directly regulate $\mathrm{mTERT}$ by interacting with the core promoter region or indirectly promote mTERT transcription by regulating or synergistically cooperating with Sp1 and Sp3. ${ }^{24}$ In this study, we demonstrated that Zfp637 binds to the mTERT promoter $(-535 /-502)$ specifically and activates the transcription of mTERT directly. However, the sequence of the Zfp637-binding site has not yet been elucidated and further experiments are needed to explore the Zfp637-responsive elements. It is likely that Zfp637 and other transcription factors activate the transcription of mTERT in a collaborative manner, and this possibility remains to be confirmed.

In conclusion, our study provides the first illumination of the mechanism through which Zfp637 protects cells against oxidative stress-induced premature senescence. As delineated in Figure 7, under conventional conditions, Zfp637 binds to the MTERT promoter and transcriptionally activates mTERT. mTERT expression maintains telomerase activity and telomere length and promotes cell proliferation. However, the oxidative stress-triggered downregulation of Zfp637 results in depressed binding of Zfp637 to the mTERT promoter. As a consequence, reduced levels of mTERTdependent telomerase activity and accelerated telomere shortening lead to cellular senescence. Zfp637 overexpression rescues the telomerase activity, maintains telomere, and prevents oxidative stress-induced premature senescence.

\section{Materials and Methods}

Cell culture and treatment. NIH3T3 and $\mathrm{C} 2 \mathrm{C} 12$ cells were obtained from American Type Culture Collection and maintained in Dulbecco's modified Eagle's medium supplemented with $10 \%$ fetal bovine serum, $100 \mathrm{U} / \mathrm{ml}$ penicillin, and $100 \mathrm{mg} / \mathrm{ml} \mathrm{streptomycin}$. Cells were sustained at $37^{\circ} \mathrm{C}$ in humidified $95 \%$ air and $5 \%$ $\mathrm{CO}_{2}$ atmosphere. For the induction of senescence, cells were cultured in medium containing $100 \mu \mathrm{M} \mathrm{H}_{2} \mathrm{O}_{2}$ (Shanghai Biochemical Reagent Company, Shanghai, China) or $8 \mathrm{~g} / \mathrm{D}$-gal (Sigma Chemical Company, St. Louis, MO, USA) for $96 \mathrm{~h}$.

Annexin V-FITC-binding assay for apoptosis. Apoptotic cells were quantified by Annexin V-FITC and propidium iodide double staining using a staining kit from KeyGEN Biotech (Nanjing, China). Briefly, cells were trypsinized, washed with phosphate-buffered saline (PBS) twice, and resuspended in $200 \mu \mathrm{l}$ of binding buffer containing $2 \mu \mathrm{l}$ of Annexin V-FITC and $2 \mu \mathrm{l}$ of propidium iodide. The suspension was incubated at room temperature for $15 \mathrm{~min}$. The cell mixture was subsequently analyzed by a flow cytometer (FACAria, Becton Dickinson, Franklin Lakes, NJ, USA). A total of $1 \times 10^{4}$ events were collected from each sample. Analysis of the multivariate data was performed with FSC Express Version 3 software (Becton Dickinson).

LDH release assay. Cell necrosis was assessed by measuring the release of the cytosolic enzyme, LDH. The culture supernatant $(100 \mu l)$ from each sample was transferred into a 96-well plate and then incubated with lactic acid dehydrogenase substrate mixture at $37^{\circ} \mathrm{C}$ for $10 \mathrm{~min}$. The reaction was stopped with $1 \mathrm{M}$ citric acid solution. The absorbance was measured using a microtiter 
plate reader (Bio-rad 680, Bio-Rad Laboratories Inc, Hercules, CA, USA) at $570 \mathrm{~nm}$ and the level of released LDH ( $\left.\mathrm{LDH}_{\text {supernatant }}\right)$ was assessed. Cells were collected and adequately lysed in 1\% NP40 solution, and then intracellular LDH level was determined. The percentage of released LDH was calculated as follows:

$$
\% \mathrm{LDH} \text { release }=\mathrm{LDH}_{\text {supernatant }} /\left(\mathrm{LDH}_{\text {supernatant }}+\mathrm{LDH}_{\text {cell }}\right) \times 100 \text {. }
$$

Cell counting. Cell counting was performed at $0,24,48,72$, and $96 \mathrm{~h}$ after exposure to $\mathrm{H}_{2} \mathrm{O}_{2}$ or $\mathrm{D}$-gal. Cells were harvested by trypsinization and viable cells were counted using a hemocytometer. Experiments were performed in triplicate. The cell number ratios of each check point to starting point were determined to evaluate the cell proliferation.

SAHF analysis by DAPI staining. Cells were fixed with $4 \%$ paraformaldehyde for $10 \mathrm{~min}$ at room temperature and incubated with DAPI staining solution (Beyotime Institute of Biotechnology, Shanghai, China) for $5 \mathrm{~min}$. After rinsed three times in PBS, cells were observed using a fluorescence microscope (Olympus, Hamburg, Germany). The percentage of SAHF-positive cells was determined by counting cells with compacted punctate foci from 10 fields of view under each condition.

SA- $\beta$-gal assay. SA- $\beta$-gal activity was measured using an $\mathrm{SA}-\beta$-gal staining kit (Beyotime Institute of Biotechnology). Briefly, cells were rinsed in PBS and fixed for $15 \mathrm{~min}$ at room temperature in a fixing solution of the $S A-\beta$-gal kit. After washed in PBS, cells were incubated in senescence detection solution overnight at $37^{\circ} \mathrm{C}$. Subsequently, cells were observed under a light microscope. The percentage of SA- $\beta$-gal-positive cells was determined by counting blue-stained cells from 10 fields of view under each condition. $5 \mu \mathrm{m}$ frozen sections of tissues from BALB/C mice were fixed and then incubated in senescence detection solution at $37^{\circ} \mathrm{C}$ overnight. Tissue sections were counterstained with eosin as described previously ${ }^{52}$ and examined under the microscope.

Measurement of intracellular ROS. To assess the intracellular ROS level, cells were washed with Dulbecco's modified Eagle's medium twice and then incubated with $5 \mu \mathrm{M} 2^{\prime}, 7^{\prime}$-dichlorodihydrofluorescein diacetate (DCFHDA; Jiancheng Bioengineering Institute, Nanjing, China) at $37^{\circ} \mathrm{C}$ for $30 \mathrm{~min}$. Then, cells were washed with PBS and lysed in lysis buffer. The fluorescence intensity was measured by Fluoroskan Ascent FL (Thermo Electron Corporation, Waltham, MA, USA) with the setting of $485 \mathrm{~nm}$ (excitation) and $530 \mathrm{~nm}$ (emission). To estimate the ROS level in tissues, $0.1 \mathrm{~g}$ tissue was homogenized in $1 \mathrm{ml}$ normal saline, and the homogenate supernatant was 10 fold diluted. $100 \mu \mathrm{l}$ diluted supernatant and DCFH-DA $(10 \mu \mathrm{M})$ were mixed and incubated at $37^{\circ} \mathrm{C}$ for $30 \mathrm{~min}$, Then, the fluorescence intensity was measured by Fluoroskan Ascent FL. Protein concentrations of cell samples and tissue homogenates were determined using Bio-Rad Protein Assay (Bio-Rad Laboratories $\mathrm{Inc}$ ). The ratios of fluorescence intensity to protein concentration were calculated to normalize the results.

Measurement of telomerase activity. Telomerase activity was detected by a modified protocol described previously. ${ }^{53}$ Briefly, total cell or tissue extracts were prepared according to the protocol of the telomerase PCR- ELISA kit (Roche Diagnostics, Mannheim, Germany). Then, telomerase activity of extracts was measured by the telomerase PCR-ELISA, according to the manufacturer's instructions. PCR products were detected by the photometric enzyme immunoassay and the absorbance was measured by the Model 680 microplated reader at $450 \mathrm{~nm}$. All assays were performed in triplicate. The level of telomerase activity in positive-control cell extract supplied in the kit was set to $100 \%$ and the relative telomerase activity of each extract was calculated compared with positive control.

Zfp637 gene silencing. Zfp637 knockdown was performed with the specific shRNA-targeting Zfp637. The shRNA sequences were as follows: shRNA-Zfp637, $5^{\prime}$-GGGCAACCTGGTTACACATCA-3' and shNC, 5'-TTCTCCGAACGTGTCA GGT-3'. Recombinant lentivirus vector (pGLVU6/Puro) targeting (shRNAZfp637) or non-targeting (shNC) were purchased from Gene Pharma Company (Shanghai, China). To establish cell lines with Zfp637 stably knocked down, cells were infected with the recombinant lentivirus (named shNC and shZfp637 cells, respectively). Forty-eight hours post infection, $50 \mu \mathrm{g} / \mathrm{ml}$ puromycin was utilized to eliminate the uninfected cells.
Cell transfection. To obtain cells overexpressing Zfp637, $8 \times 10^{3}$ cells per well in a 96-well plate or $1.5 \times 10^{5}$ cells per well in a 6 -well plate were transfected with 0.25 or $4 \mu \mathrm{g}$ of the pcDNA3.1-Zfp637/pEGFP-Zfp637 plasmid using TurboFect (Fermentas, St. Leon-Rot, Germany), respectively. For mTERT knockdown in NIH3T3 cells overexpressing Zfp637, $1.5 \times 10^{5}$ cells per well in a six-well plate were co-transfected with $40 \mathrm{pmol}$ siRNA-mTERT and $4 \mu \mathrm{g}$ pcDNA3.1-Zfp637 using TurboFect (Fermentas). siRNA-targeting mTERT was synthesized by Gene Pharma Company with the following sequences: $5^{\prime}$-CAGAU CAAGAGCAGUAGUCTT-3' (sense) and 5'-GACUACUGCUCUUGAUCUGTT- $3^{\prime}$ (antisense). ${ }^{54}$

RNA isolation and qRT-PCR. Total RNA was isolated using RNAiso plus (TAKARA, Tokyo, Japan), and converted to cDNA using a PrimeScript RT reagent kit (TAKARA) according to the manufacturer's instructions. qRT-PCR was performed with SYBR Green Master Mix (TAKARA) in an iCycler iQ Multicolor Real-Time Detection System (Bio-Rad, Tokyo, Japan). The primer sequences were as follows. Zfp637: forward, $5^{\prime}$-GCCTTTTTCAATGTGATGACAGA-3' and reverse, 5'-TCCCACATTCCTGGCAATC-3'; mTERT: forward, 5'-GCGGTTGAAG TGTCACGGTCTATT- $3^{\prime}$ and reverse, $5^{\prime}$-TTCCTAACACGCTGGTCAAAGGG-3'; and glyceraldehyde phosphate dehydrogenase: forward, $5^{\prime}$-ACCACAGTCCATGC CATCAC- $3^{\prime}$ and reverse, $5^{\prime}$-TCCACCACCCTGTTGCTGTA- $3^{\prime}$. Amplification involved initial denaturation at $95{ }^{\circ} \mathrm{C}$ for $10 \mathrm{~s}$ followed by 40 cycles of denaturation at $95^{\circ} \mathrm{C}$ for $5 \mathrm{~s}$ and annealing and extension at $60^{\circ} \mathrm{C}$ for $45 \mathrm{~s}$. Reactions were performed in triplicate and the mRNA expression was normalized against the internal control gene glyceraldehyde phosphate dehydrogenase. Data were analyzed using Gene Expression Macro Version 1.1 software (Bio-Rad Laboratories Inc.).

DNA isolation and measurement of telomere length by qRT-PCR. Genomic DNA was extracted from cells using a Genomic DNA isolation kit (Promega, Madison, WI, USA). Relative telomere length was measured from genomic DNA by qRT-PCR as previously described. ${ }^{33,34}$ The premise of this assay is to measure an average telomere length ratio by quantifying telomeric DNA $(T)$ and to divide that amount by the quantity of a singlecopy gene $(S)$, the acidic ribosomal phosphoprotein PO (36B4) gene, which is well-conserved and used for gene-dosage studies. The primer sequences were as follows. ${ }^{34}$ Telomere: forward, $5^{\prime}$-CGGTTTGTTTGGGTTTGGGTTTGGGTTTGGGT TTGGGTT- $3^{\prime}$ and reverse, $5^{\prime}$-GGCTTGCCTTACCCTTACCCTTACCCTTACCCTT ACCCT-3'; 36B4: forward, 5'-ACTGGTCTAGGACCCGAGAAG-3' and reverse, $5^{\prime}$-TCAATGGTGCCTCTGGAGATT-3'. Standard curves were generated for telomere and 36B4 amplification reactions, using an individual DNA sample from $\mathrm{NIH} 3 \mathrm{~T} 3$ cells serially diluted over a 16 -fold range, from 6.25 to $60 \mathrm{ng}$ per reaction (Supplementary Figure 7). To measure the telomere length, triplicate $25 \mu$-volume PCR reactions included $12.5 \mu$ l SYBR Green PCR Master Mix (TAKARA), $400 \mathrm{nM}$ forward and reverse primers, $20 \mathrm{ng}$ genomic DNA, and enough double-distilled $\mathrm{H}_{2} \mathrm{O}$. An iCycler iQ Multicolor Real-Time Detection System was used and the reaction condition was set as $95^{\circ} \mathrm{C}$ for $30 \mathrm{~s}$ followed by 40 cycles of data collection at $95{ }^{\circ} \mathrm{C}$ for $5 \mathrm{~s}$ and a $56^{\circ} \mathrm{C}$ anneal-extend step for $1 \mathrm{~min}$. The amount ratio of telomere to $36 \mathrm{~B} 4$ was calculated as follows: $T / S$ ratio $=2^{-\left[C_{t} \text { (telo) }-C_{\text {, }}\right.}$ (36b4)] $=2^{-\Delta C_{1} 53}$ The relative $T / S$ ratio $(T / S$ of one sample relative to the average $\mathrm{T} / \mathrm{S}$ of $\mathrm{H}_{2} \mathrm{O}_{2}$ treatment group) is $2^{-\left(\Delta \mathrm{C}_{\mathrm{t}}-\Delta \mathrm{C}_{\mathrm{H}} \mathrm{H}\right)}=2^{-\Delta \Delta \mathrm{C}_{1} 55}$

Western blot analysis. The cells were collected and washed with PBS and then lysed with lysis buffer ( $50 \mathrm{mM}$ Tris- $\mathrm{HCl}, 150 \mathrm{mM} \mathrm{NaCl}, 1 \mathrm{mM}$ EDTA, $50 \mathrm{mM}$ $\mathrm{NaF}, 30 \mathrm{mM} \mathrm{Na} \mathrm{P}_{2} \mathrm{O}_{7}, 1 \mathrm{mM}$ phenylmethylsulfonyl fluoride, $2 \mu \mathrm{g} / \mathrm{ml}$ aprotinin) for $30 \mathrm{~min}$ in the ice. After the protein concentrations were determined using the Bio-Rad Protein Assay, the equal amount of extracted protein was loaded, separated by $12 \%$ SDS-PAGE, and transferred to a polyvinylidene difluoride membrane (Millipore, Bedford, MA, USA). After blocked with TBST (10 mM Tris$\mathrm{HCl}, \mathrm{pH} 8.0,150 \mathrm{mM} \mathrm{NaCl}, 0.1 \%$ Tween-20) containing $5 \%$ skimmed milk for $1 \mathrm{~h}$ at $37^{\circ} \mathrm{C}$, the membrane was incubated with primary antibody at $4{ }^{\circ} \mathrm{C}$ overnight. Antibodies and their sources were as follows: anti-Zfp637 antibody $(1: 50)$ was produced and purified as previously described; ${ }^{28}$ anti-p53 antibody $(1: 1000)$ was purchased from Cell Signaling Technology (Beverly, MA, USA); anti- $\beta$-actin antibody $(1: 1000)$ and anti-mTERT antibody $(1: 500)$ were purchased from Santa Cruz Biotechnology (Santa Cruz, CA, USA). After incubation with primary antibody, membrane was washed with TBST and then incubated with horseradish peroxidase-conjugated goat-anti-rabbit/mouse antibody (Santa Cruz Biotechnology) for $1 \mathrm{~h}$ at room temperature. After washed with TBST, the membrane was 
developed using Immobilon Western Chemiluminescent horseradish peroxidase Substrate (Millipore).

Generation of mTERT promoter constructs. $5^{\prime}$-Flanking region of mTERT with different length was generated from genomic DNA by PCR with the following forward primers: mTERT $(-1024 /+53), \quad 5^{\prime}$-TTCGCCTGGTAC CTCGGTGGATAGA-3'; mTERT $(-925 /+53), \quad$ 5'-ACCGCAGAGGTACCA GATTCC CTATTTC-3'; mTERT $(-689 /+53), \quad 5^{\prime}$-TTACCTTGGTACCGGTG CGTGAGTTG-3'; mTERT $(-535 /+53), \quad 5^{\prime}$-GTCGCACCGGTACCAAGCCT TAACC-3'; mTERT $(-501 /+53), \quad 5^{\prime}$-TGGCCGGTACCATCATTAAGAACT GAGA-3'; mTERT ( - 467/ + 53), 5'-ACCACCGGTACCACTGTCTGTGTCAAC-3'; mTERT $(-433 /+53), 5^{\prime}$-TGCTGAGGTACCCAGCTCAGGAACAG-3'; mTERT $(-399 /$ + 53), 5'-GCCTTAGGTGGTACCGCCTACCTAACC-3'; mTERT $(-245 /$ +53), 5'-CGCTCCGGTACCTTACTCCAACACATC- ${ }^{\prime}$; mTERT $(-128 /+53)$, $5^{\prime}$-TGCCGGTACCTACAACGCTTGGTC- $3^{\prime}$. The following reverse primer was used: $5^{\prime}$-AGAGCGAAGCTTGGGGCAACGA-3'. Kpnl restriction sites were shown in boldface, and the HindllI restriction site was in italic. All the PCR products were cloned into the luciferase-based vector pGL3-basic (Promega).

Dual luciferase reporter assay. NIH3T3 cells were co-transfected with $0.25 \mu \mathrm{g}$ mTERT promoter reporter construct and $0.05 \mu \mathrm{g} \mathrm{pRL-TK}$ (Promega) with or without $0.75 \mu \mathrm{g}$ pcDNA3.1-Zfp637 using $2 \mu \mathrm{l}$ TurboFect Transfection Reagent (Fermentas) per well in 48-well plates. Twenty-four hours post transfection, cells were rinsed twice with PBS and incubated in medium containing $100 \mu \mathrm{M} \mathrm{H}_{2} \mathrm{O}_{2}$ or $8 \mathrm{~g} / \mathrm{l} \mathrm{D}$-gal for another $96 \mathrm{~h}$. Cells were lysed in Passive Lysis Buffer (Promega), and then used to measure luciferase activity. The dual-luciferase reporter assay was performed using Multi-Mode Microplate Reader (Synergy2, Bioteck) according to the manufacturer's instructions (Promega). Three independent experiments were performed under each condition.

EMSA. The GST-Zfp637 fusion protein was constructed and purified as described previously. ${ }^{28}$ Nuclear extracts were prepared using ProteoJET Cytoplasmic and Nuclear Protein Extraction Kit (Fermentas) according to the manufacturer's instruction. GST-Zfp637 fusion protein or nuclear protein was incubated with the following $5^{\prime}$-end biotin-labeled double-stranded oligonucleotides: mTERT (-535/-502), 5'-AAGCCTTAACCTATATAGTAGAATTTCAG CTGTA-3'. The binding reaction was performed for $20 \mathrm{~min}$ at room temperature using the LightShift Chemiluminescent EMSA Kit (Pierce Biotechnology, Rockford, IL, USA). The protein-DNA complexes were separated by electrophoresis with a $5 \%$ nondenaturing polyacrylamide gel and then transferred to the positively charged nylon membrane (Millipore). Subsequently, the membrane was developed using Chemiluminescent Nucleic Acid Detection Module (Pierce Biotechnology) according to the instructions of the manufacturer. For competition assays, nuclear extracts were incubated with a 200 -fold molar excess of unlabeled doublestranded competitor oligonucleotides.

Obtaining tissues from mice. The 8-week-old and 10-month-old male BALB/C mice were purchased from Experimental Animal Center of Sichuan University (Chengdu, China). Each experimental group consisted of five mice. To obtain tissues, mice were killed, and then the blood vessel, cerebellum, cerebrum, heart, kidney, liver, lung, spleen, testicle tissues were collected. All animals received humane care according to the Institutional Animal Care and Treatment Committee of Sichuan University.

Statistical analysis. All quantitative data were expressed as means \pm S.D. To determine significance between two groups, comparisons between means were made using the Student's t-test. Multiple group comparisons were performed with one-way analysis of variance using the statistical software SPSS 13.0 (SPSS, Chicago, IL, USA). $P$-value $<0.05$ was considered statistically significant for three or more independent experiments.

\section{Conflict of Interest}

The authors declare no conflict of interest.

Acknowledgements. This study was supported by the items (31070675) from National Natural Science Foundation of China and by the grants from the National 973 Basic Research Program of China (2013CB911300). This work was also supported by Sichuan Province foundation (2010JY0055) from Science and Technology Department of Sichuan Province and by Project fund (2014M552367) from China Postdoctoral Science Foundation.

1. Demidenko ZN, Blagosklonny MV. Growth stimulation leads to cellular senescence when the cell cycle is blocked. Cell Cycle 2008; 7: 3355-3361.

2. Blackburn EH. Switching and signaling at the telomere. Cell 2001; 106: 661-673.

3. Courtois-Cox S, Genther Williams SM, Reczek EE, Johnson BW, McGillicuddy LT, Johannessen $\mathrm{CM}$ et al. A negative feedback signaling network underlies oncogeneinduced senescence. Cancer Cell 2006; 10: 459-472.

4. Thaler S, Hähnel PS, Schad A, Dammann R, Schuler M. RASSF1A mediates p21Cip1/Waf1-dependent cell cycle arrest and senescence through modulation of the Raf-MEK-ERK pathway and inhibition of Akt. Cancer Res 2009; 69: 1748-1757.

5. Dong C, Wang X, Wang G, Zhang W, Zhu L, Gao S et al. A stress-induced cellular aging model with postnatal neural stem cells. Cell Death Dis 2014; 5: e1116.

6. Magenta A, Cencioni C, Fasanaro P, Zaccagnini G, Greco S, Sarra-Ferraris G et al. $\mathrm{miR}-200 \mathrm{c}$ is upregulated by oxidative stress and induces endothelial cell apoptosis and senescence via ZEB1 inhibition. Cell Death Differ 2011; 18: 1628-1639.

7. Biesalski H. Free radical theory of aging. Curr Opin Clin Nutr Metab care 2002; 5: 5-10.

8. Lu T, Finkel T. Free radicals and senescence. Exp Cell Res 2008; 314: 1918-1922.

9. de Magalhães JP, Chainiaux F, de Longueville F, Mainfroid V, Migeot V, Marcq L et al. Gene expression and regulation in $\mathrm{H}_{2} \mathrm{O}_{2}$-induced premature senescence of human foreskin fibroblasts expressing or not telomerase. Exp Gerontol 2004; 39: 1379-1389.

10. Frippiat C, Chen QM, Zdanov S, Magalhaes J-P, Remacle J, Toussaint O. Subcytotoxic $\mathrm{H}_{2} \mathrm{O}_{2}$ stress triggers a release of transforming growth factor- $\beta 1$, which induces biomarkers of cellular senescence of human diploid fibroblasts. J Biol Chem 2001; 276: 2531-2537.

11. Xie X, Zhang H, Gao P, Wang L, Zhang A, Xie S et al. Overexpression of SIRT6 in porcine fetal fibroblasts attenuates cytotoxicity and premature senescence caused by D-galactose and tert-butylhydroperoxide. DNA Cell Biol 2012; 31: 745-752.

12. Yi H, Li XH, Yi B, Zheng J, Zhu G, Li C et al. Identification of Rack1, EF-Tu and Rhodanese as aging-related proteins in human colonic epithelium by proteomic analysis. $J$ Proteome Res 2010; 9: 1416-1423.

13. Parameshwaran K, Irwin MH, Steliou K, Pinkert CA. D-Galactose effectiveness in modeling aging and therapeutic antioxidant treatment in mice. Rejuvenation Res 2010; 13: 729-735.

14. Kumar A, Prakash A, Dogra S. Naringin alleviates cognitive impairment, mitochondrial dysfunction and oxidative stress induced by D-galactose in mice. Food Chem Toxicol 2010; 48: 626-632.

15. Shay JW, Wright WE. Role of telomeres and telomerase in cancer. Semin Cancer Biol 2011; 21: 349-353.

16. Lewis KA, Wuttke DS. Telomerase and telomere-associated proteins: structural insights into mechanism and evolution. Structure 2012; 20: 28-39.

17. Martín-Rivera L, Herrera E, Albar JP, Blasco MA. Expression of mouse telomerase catalytic subunit in embryos and adult tissues. Proc Natl Acad Sci USA 1998; 95: 10471-10476.

18. Colgin LM, Reddel RR. Telomere maintenance mechanisms and cellular immortalization. Curr Opin Genet Dev 1999; 9: 97-103.

19. Nakayama J, Tahara H, Tahara E, Saito M, Ito K, Nakamura H et al. Telomerase activation by hTRT in human normal fibroblasts and hepatocellular carcinomas. Nat Genet 1998; 18: 65-68.

20. Geserick C, Tejera A, Gonzalez-Suarez E, Klatt P, Blasco M. Expression of mTert in primary murine cells links the growth-promoting effects of telomerase to transforming growth factor- $\beta$ signaling. Oncogene 2006; 25: 4310-4319.

21. Tomás-Loba A, Flores I, Fernández-Marcos PJ, Cayuela ML, Maraver A, Tejera A et al. Telomerase reverse transcriptase delays aging in cancer-resistant mice. Cell 2008; 135: $609-622$.

22. Kyo S, Takakura M, Taira T, Kanaya T, Itoh H, Yutsudo M et al. Sp1 cooperates with c-Myc to activate transcription of the human telomerase reverse transcriptase gene (hTERT). Nucleic Acids Res 2000; 28: 669-677.

23. Yin L, Hubbard AK, Giardina C. NF- $\kappa B$ regulates transcription of the mouse telomerase catalytic subunit. J Biol Chem 2000; 275: 36671-36675.

24. Li K, Zhang J, Ren JJ, Wang Q, Yang KY, Xiong ZJ et al. A novel zinc finger protein Zfp637 behaves as a repressive regulator in myogenic cellular differentiation. J Cell Biochem 2010; 110: 352-362.

25. Beyer TA, Xu W, Teupser D, Bugnon P, Hildt E, Thiery J et al. Impaired liver regeneration in Nrf2 knockout mice: role of ROS-mediated insulin/IGF-1 resistance. EMBO J 2008; 27: 212-233.

26. Deschênes F, Massip L, Garand C, Lebel M. In vivo misregulation of genes involved in apoptosis, development and oxidative stress in mice lacking both functional Werner syndrome protein and poly (ADP-ribose) polymerase-1. Hum Mol Genet 2005; 14 : 3293-3308.

27. Nojiri H, Shimizu T, Funakoshi M, Yamaguchi O, Zhou H, Kawakami S et al. Oxidative stress causes heart failure with impaired mitochondrial respiration. J Biol Chem 2006; 281: 33789-33801.

28. Li K, Wei Y, Zhang J, Li J, Gao B, Huang L et al. Cytoplasmic expression, antibody production, and characterization of the novel zinc finger protein 637. Appl Microbiol Biotechnol 2013; 97: 741-749. 
29. Zhang R, Chen W, Adams PD. Molecular dissection of formation of senescenceassociated heterochromatin foci. Mol Cell Biol 2007; 27: 2343-2358.

30. Vigneron A, Vousden KH. p53, ROS and senescence in the control of aging. Aging 2010; 2 471-474.

31. Estrada J, Torres Y, Benguría A, Dopazo A, Roche E, Carrera-Quintanar L et al. Human mesenchymal stem cell-replicative senescence and oxidative stress are closely linked to aneuploidy. Cell Death Dis 2013; 4: e691.

32. von Zglinicki T, Pilger R, Sitte N. Accumulation of single-strand breaks is the major cause of telomere shortening in human fibroblasts. Free Radic Biol Med 2000; 28: 64-74.

33. Gil ME, Coetzer TL. Real-time quantitative PCR of telomere length. Mol Biotechnol 2004 27: $169-172$.

34. Callicott RJ, Womack JE. Real-time PCR assay for measurement of mouse telomeres. Comp Med 2006; 56: 17-22.

35. Wright WE, Piatyszek MA, Rainey WE, Byrd W, Shay JW. Telomerase activity in human germline and embryonic tissues and cells. Dev Genet 1996; 18: 173-179.

36. Pan C, Xue BH, Ellis TM, Peace DJ, Díaz MO. Changes in telomerase activity and telomere length during human T lymphocyte senescence. Exp Cell Res 1997; 231: 346-353.

37. Harman D, Holliday R, Meydani M. Towards prolongation of the healthy life span. Ann NY Acad Sci 1998; 854: 23-26.

38. Vaziri H, Benchimol S. Reconstitution of telomerase activity in normal human cells leads to elongation of telomeres and extended replicative life span. Curr Biol 1998; 8: 279-282.

39. Prowse KR, Greider CW. Developmental and tissue-specific regulation of mouse telomerase and telomere length. Proc Natl Acad Sci USA 1995; 92: 4818-4822.

40. Kong Z, Li M, Yang W, Xu W, Xue Y. A novel nuclear-localized CCCH-type zinc finger protein, OsDOS, is involved in delaying leaf senescence in rice. Plant Physiol 2006; 141: 1376-1388.

41. Shibanuma M, Mashimo J-i, Kuroki T, Nose K. Characterization of the TGF beta 1-inducible hic-5 gene that encodes a putative novel zinc finger protein and its possible involvement in cellular senescence. J Biol Chem 1994; 269: 26767-26774.

42. Hemann MT, Narita M. Oncogenes and senescence: breaking down in the fast lane. Genes Dev 2007; 21: 1-5.

43. Kennedy AL, McBryan T, Enders GH, Johnson FB, Zhang R, Adams PD. Senescent mouse cells fail to overtly regulate the HIRA histone chaperone and do not form robust Senescence Associated Heterochromatin Foci. Cell Div 2010; 5: 16.

44. Serra V, Von Zglinicki T, Lorenz M, Saretzki G. Extracellular superoxide dismutase is a major antioxidant in human fibroblasts and slows telomere shortening. J Biol Chem 2003; 278: $6824-6830$.

45. Von Zglinicki T. Oxidative stress shortens telomeres. Trends Biochem Sci 2002; 27: 339-344.
46. von Zglinicki T, Petrie J, Kirkwood TB. Telomere-driven replicative senescence is a stress response. Nat Biotechnol 2003; 21: 229-230.

47. Bodnar AG, Ouellette M, Frolkis M, Holt SE, Chiu C-P, Morin GB et al. Extension of life-span by introduction of telomerase into normal human cells. Science 1998; 279: 349-352.

48. Ahmed S, Passos JF, Birket MJ, Beckmann T, Brings S, Peters H et al. Telomerase does not counteract telomere shortening but protects mitochondrial function under oxidative stress. J Cell Sci 2008; 121: 1046-1053.

49. Finkel T, Holbrook NJ. Oxidants, oxidative stress and the biology of ageing. Nature 2000; 408: 239-247.

50. Li H, Liu J-P. Signaling on telomerase: a master switch in cell aging and immortalization. Biogerontology 2002; 3: 107-116.

51. Park NH, Guo W, Kim HR, Kang MK, Park NH. c-Myc and Sp1/3 are required for transactivation of hamster telomerase catalytic subunit gene promoter. Int J Oncol 2001; 19: $755-761$.

52. Zhuo L, Cai G, Liu F, Fu B, Liu W, Hong Q et al. Expression and mechanism of mammalian target of rapamycin in age-related renal cell senescence and organ aging. Mech Ageing Dev 2009; 130: 700-708.

53. Ping L, Asai A, Okada A, Isobe K, Nakajima H. Dramatic increase of telomerase activity during dendritic cell differentiation and maturation. J Leuko Biol 2003; 74: 270-276.

54. Wei W, Lv P-P, Chen X-M, Yue Z-G, Fu Q, Liu S-Y et al. Codelivery of mTERT siRNA and paclitaxel by chitosan-based nanoparticles promoted synergistic tumor suppression. Biomaterials 2013; 34: 3912-3923.

55. Cawthon RM. Telomere measurement by quantitative PCR. Nucleic Acids Res 2002; 30: e47.

(c) (i) () $\Theta$ Cell Death and Disease is an open-access journal c) published by Nature Publishing Group. This work is licensed under a Creative Commons Attribution-NonCommercialNoDerivs 3.0 Unported License. The images or other third party material in this article are included in the article's Creative Commons license, unless indicated otherwise in the credit line; if the material is not included under the Creative Commons license, users will need to obtain permission from the license holder to reproduce the material. To view a copy of this license, visit http://creativecommons.org/licenses/ by-nc-nd/3.0/

Supplementary Information accompanies this paper on Cell Death and Disease website (http://www.nature.com/cddis) 